\title{
Synthesis, in silico Study and Antimicrobial Activity of New Piperine Derivatives Containing Substituted $\delta$-Esters
}

\author{
Emmely O. Trindade, ${ }^{a}$ Thalisson F. Dutra,${ }^{a}$ Maria C. R. Brandão, ${ }^{b}$ \\ Hermes Diniz Neto, ${ }^{\circledR c}$ Edeltrudes O. Lima, ${ }^{c}$ Bruno F. Lira, ${ }^{a}$ \\ Petrônio F. de Athayde-Filho ${ }^{a}$ and José M. Barbosa-Filho ${ }^{\circledR} * c$
}

\author{
${ }^{a}$ Departamento de Química, Universidade Federal da Paraíba, 58051-900 João Pessoa-PB, Brazil \\ ${ }^{b}$ Instituto Federal da Paraíba, Campus Areia, 58397-000 Areia-PB, Brazil \\ 'Departamento de Ciências Farmacêuticas, Universidade Federal da Paraíba, \\ 58051-900 João Pessoa-PB, Brazil
}

\begin{abstract}
A series of fifteen new piperine-derived diesters was synthesized through the substitution reaction between the salt of piperic acid, obtained through piperine basic hydrolysis, with the $\delta$-chloro-esters, obtained through the cleavage of tetrahydrofuran (THF) with acyl chlorides in the presence of $\mathrm{ZnCl}_{2}$. The final compounds were obtained with yields ranging from 50 to $84 \%$ and were characterized by infrared (IR) and ${ }^{1} \mathrm{H}$ and ${ }^{13} \mathrm{C}$ nuclear magnetic resonance spectroscopy (NMR). The new compounds were evaluated in silico in regard to their ADME (absorption, distribution, metabolism, and excretion) properties, and in vitro for their antimicrobial activity against bacteria strains (Staphylococcus aureus and Pseudomonas aeruginosas), yeast fungi (Candida albicans and $C$. tropicalis) and filamentous fungi (Aspergillus fumigatus, A. flavus and A. niger). The results from the in silico studies of Lipinski's rule of five showed that most compounds present good pharmacological possibilities, and the results from in vitro antimicrobial activity showed that 8 of the 15 synthesized compounds displayed antimicrobial activity, inhibiting the growth of $40-80 \%$ of tested strains, with a minimum inhibitory concentration (MIC) interval ranging from 1024 to $256 \mu \mathrm{g} \mathrm{mL}^{-1}$.
\end{abstract}

Keywords: piperine derivatives, diesters, antimicrobial activity, in silico study

\section{Introduction}

The black pepper (Piper nigrum L.) is one of the most consumed spices in the world, as well as the main spice in the food, medical, perfumery and cosmetic industries. ${ }^{1,2}$ Its seeds have been used for centuries as a condiment in food preparation, and in folk medicine, in preparations, such as ointments and creams for the treatment of various diseases, given their therapeutic actions. ${ }^{3}$ Many of the activities associated with the black pepper fruits are due to its main active principle, piperine, a natural alkaloid with molecular formula $\mathrm{C}_{17} \mathrm{H}_{19} \mathrm{NO}_{3}$ that is extractable with 3-7\% yield from the fruits of several species of the Piper genus. ${ }^{4,5}$

Piperine has a wide spectrum of biological activities, such as antioxidant, antitumor, antimicrobial, anti-inflammatory, immunomodulatory, hepatoprotective, antiasthmatic,

*e-mail: jbarbosa@ltf.ufpb.br anticonvulsant, antimutagenic, antidepressant, anti-thyroid, and still others. ${ }^{67}$ Piperine has received substantive attention in the last two decades, and has been considered an extremely versatile bioactive molecule. ${ }^{8}$ Its structure allows several chemical changes, and this has been playing an important role in the synthesis of new derived compounds with therapeutic application in multiple human diseases. Piperine derivatives displayed anti-inflammatory activity, ${ }^{9}$ analgesic, ${ }^{9}$ antimicrobial,${ }^{10}$ antitumor, ${ }^{11}$ antidiabetic, ${ }^{12}$ antichagasic, ${ }^{13}$ anti-vitiligo ${ }^{14}$ and yet other pharmacological properties. Many derivatives showed biological activities superior to that of piperine itself, and thus emerged as a new approach in the research and discovery of new drugs.

Among the various activities presented by piperinederived compounds, antimicrobial activity deserves emphasis. That is largely because the number of microorganisms resistant to available drugs increases more and more, reaching alarming levels. Hence, effective 
treatment of infections caused by resistant fungi and bacteria is becoming increasingly challenging for public health systems. ${ }^{15,16}$ Therefore, there is an increasing need of research, identification and development of new biologically active molecules capable of containing these emerging microbial infections. ${ }^{17}$

In view of these aspects, the use of piperine extracted from black pepper is present in this work, as a good source for the discovery of new molecules with potential antimicrobial activities. For this, a series of $\delta$-chloro-esters was planned and synthesized, which were coupled to the piperinic segment in order to originate fifteen new piperinederived diesters, with their biological potential evaluated through in silico study and in vitro antimicrobial activity.

\section{Results and Discussion}

\section{Chemistry}

The new piperine-derived diesters (7a-7o) were efficiently planned and synthesized through six steps, which are described in Scheme 1.

Piperine (1), previously extracted from black pepper, was hydrolyzed with $\mathrm{KOH}(i)$ and then acidified (ii) to provide piperic acid (2). ${ }^{18}$ It was decided to employ potassium piperate (3) as reaction nucleophile, due to its easy removal from the reaction medium by the addition of water, and it was obtained through the neutralization reaction of piperic acid with $\mathrm{KOH}$ ethanolic solution (1:1) (iii). For the synthesis of intermediate $\delta$-chloro-esters compounds (6a-6o), acid chlorides $(\mathbf{5 a}-\mathbf{5 0})$ were initially obtained through the acyl nucleophilic substitution reaction $\left(\mathrm{S}_{\mathrm{N}} \mathrm{Ac}\right)$ between carboxylic acids $(\mathbf{4 a}-\mathbf{4 o})$ and thionyl chloride $\left(\mathrm{SOCl}_{2}\right)$, followed by the in situ reaction with tetrahydrofuran (THF) in the presence of zinc chloride $\left(\mathrm{ZnCl}_{2}\right){ }^{19}$ The final compounds $(\mathbf{7 a - 7 o})$ were obtained through the $\mathrm{S}_{\mathrm{N}} 2$ reaction between the $\delta$-chloroesters (6a-6o) and the potassium piperate (3) in slight excess to ensure that there was no residual $\delta$-chloro-ester, where this excess salt could be easily removed by the addition of water. Thus, it was possible to obtain fifteen $\delta$-chloro-esters, of which seven are new compounds ( $6 \mathbf{e}$, $\mathbf{6 i}, \mathbf{6 k}, \mathbf{6}, \mathbf{6 m}, \mathbf{6 n}$ and $\mathbf{6 o}$ ), and fifteen new piperine-derived diesters (7a-7o).

\section{Characterization of final products}

The structures of the final compounds were confirmed using infrared (IR) techniques, ${ }^{1} \mathrm{H}$ and ${ }^{13} \mathrm{C}$ nuclear magnetic resonance (NMR), including the two-dimensional (2D) NMR techniques ${ }^{1} \mathrm{H},{ }^{1} \mathrm{H}-\mathrm{COSY}$ (correlation spectroscopy), ${ }^{1} \mathrm{H},{ }^{13} \mathrm{C}-\mathrm{HSQC}$ (heteronuclear single quantum correlation) and HMBC (heteronuclear multiple bond correlation). The infrared spectra from the<smiles>[Z20]C(=O)/C=C/C=C/c1ccc2c(c1)OCO2</smiles><smiles>[R]C(=O)OCCCCCl</smiles><smiles>[R]C(=O)OCCC=COC(=O)C=CC=Cc1ccc2c(c1)OCO2</smiles>

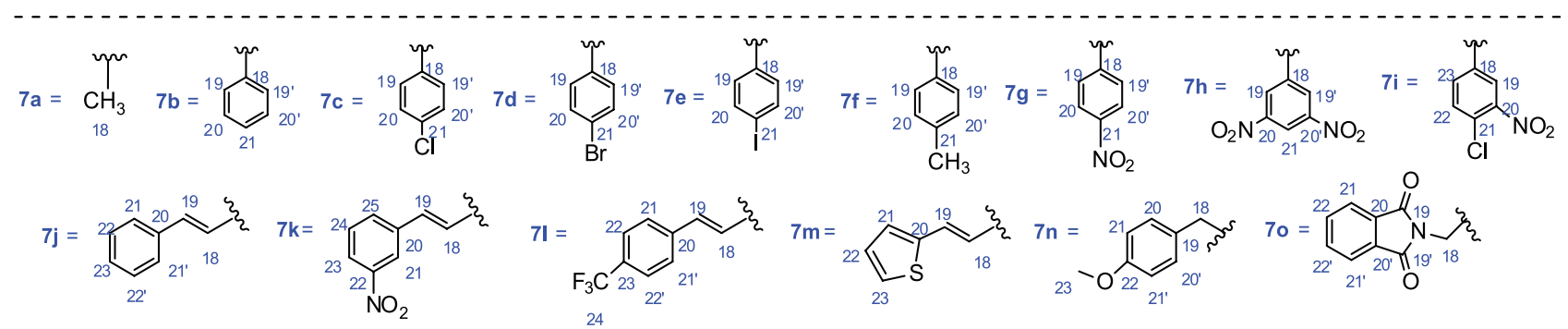

Scheme 1. Synthetic route for the synthesis of target molecules. Reagents and conditions: (i) $20 \% \mathrm{KOH}, \mathrm{EtOH}$, reflux, $20 \mathrm{~h}$; (ii) $\mathrm{HCl}$ (94\%); (iii) $\mathrm{KOH}$, $\mathrm{EtOH}$, room temperature, $1 \mathrm{~h}(93 \%)$; (iv) $\mathrm{SOCl}_{2}, \mathrm{DMF}_{\text {(cat.) }}$, reflux; (v) THF, $\mathrm{ZnCl}_{2}, 75^{\circ} \mathrm{C}(55-92 \%)$; (vi) DMF, $\mathrm{KI}, 100{ }^{\circ} \mathrm{C}(50-84 \%)$. 
diesters (7a-7o) showed the presence of the aromatic and aliphatic groups, indicated by the axial deformation of the $\mathrm{C}-\mathrm{H}$ bonds between 3103 and $3014 \mathrm{~cm}^{-1}$ alongside the angular deformation outside the plane in range or 862 and $702 \mathrm{~cm}^{-1}$ to the aromatic groups, and by the axial deformation in region between 2964 and $2858 \mathrm{~cm}^{-1}$ for the aliphatic groups, alongside the angular deformation between 2964 and $2858 \mathrm{~cm}^{-1}$ for the aliphatic groups. The axial deformations of the $\mathrm{C}=\mathrm{C}$ bonds were observed in the region of 1620-1442 $\mathrm{cm}^{-1}$. The absorptions of the carbonyl groups $(\mathrm{C}=\mathrm{O})$ appeared between 1745 and $1695 \mathrm{~cm}^{-1}$. The axial deformation band of the $\mathrm{C}-\mathrm{O}$ bond appeared around 1236 and $1016 \mathrm{~cm}^{-1}$. Around $1250 \mathrm{~cm}^{-1}$, the band referring to the methylenedioxy ring $\left(\mathrm{O}-\mathrm{CH}_{2}-\mathrm{O}\right)$ was observed, a characteristic signal of piperine-derived compounds.

Due to their similar structures, it is possible to observe that the signals referring to compounds $7 \mathbf{a}-\mathbf{7 i}$ and $\mathbf{7 n - 7 o}$ are similar to the signals referring to compound $\mathbf{7 c}$, and the signals referring to compounds $\mathbf{7 j - 7} \mathbf{m}$ are similar to the signals referring to the $\mathbf{7 k}$ compound. Thus, these compounds spectra of ${ }^{1} \mathrm{H}$ NMR, ${ }^{13} \mathrm{C}$ NMR, COSY, HMQC and $\mathrm{HMBC}$ will be detailed in this section.

In the ${ }^{1} \mathrm{H}$ NMR spectrum of the compound $\mathbf{7 c}$, signals are observed for eleven hydrogens in the aromatic and olefinic regions between $\delta_{\mathrm{H}}$ 7.97-5.97. Inside the olefinic region in $\delta_{\mathrm{H}} 6.05$, the presence of a singlet for two hydrogen atoms referring to the methylenedioxy ring is observed (H-12); in the region of $\delta_{\mathrm{H}} 5.99$, a doublet $(J 15.2 \mathrm{~Hz}, 1 \mathrm{H})$ referring to the hydrogen $\mathrm{H}-2$; and in the region of $\delta_{\mathrm{H}} 4.33-4.15$, two triplets for hydrogens H-13 and $\mathrm{H}-16$.

In the ${ }^{13} \mathrm{C}$ NMR spectra of the final compounds the presence of two carbonyls is also observed. Therefore, in order to unequivocally attribute the chemical displacements present in the compounds, the two-dimensional spectrum of heteronuclear correlations at long distance (HMBC) was used, which made it possible to mark the carbonyl of each ester subunit and the hydrogens $\mathrm{H}-13$ and $\mathrm{H}-16$, unequivocally attributing their couplings.

In the HMBC experiment for compound $\mathbf{7 c}$, the carbon signal in $\delta_{\mathrm{C}} 166.2$ couples with the signals of $\mathrm{H}-2\left(\delta_{\mathrm{H}} 5.99\right)$ and $\mathrm{H}-13\left(\delta_{\mathrm{H}} 4.16\right)$, showing that this signal corresponds to the carbonyl of the piperinic segment $(\mathrm{C}-1)$, which is, therefore, the least displaced triplet for hydrogens H-13. The signal of the second carbonyl in $\delta_{\mathrm{C}} 164.9$ couples with the signals of the hydrogens $\mathrm{H}-19$ and $\mathrm{H}-19^{\prime}\left(\delta_{\mathrm{H}} 7.96\right)$ and $\mathrm{H}-16\left(\delta_{\mathrm{H}} 4.31\right)$, corresponding to the ester carbonyl bonded to the aromatic segment (C-17).

In the two-dimensional spectrum $\left({ }^{1} \mathrm{H},{ }^{1} \mathrm{H}-\mathrm{COSY}\right)$ of compound $\mathbf{7 c}$, it is possible to observe correlations such as: the hydrogen $\mathrm{H}-3\left(\delta_{\mathrm{H}} 7.35\right)$ with the hydrogen $\mathrm{H}-2$
$\left(\delta_{\mathrm{H}} 5.99\right)$; the hydrogens $\mathrm{H}-13\left(\delta_{\mathrm{H}} 4.16\right)$ and $\mathrm{H}-16\left(\delta_{\mathrm{H}} 4.31\right)$ with the overlap of the quintets referring to the hydrogens $\mathrm{H}-14$ and $\mathrm{H}-15$ in $\delta_{\mathrm{H}}$ 1.78. Still in this spectrum, it is possible to observe the correlations between the aromatic hydrogens in para position in relation to the substituting chloro in the ring, between $\mathrm{H}-19$ and $\mathrm{H}-19^{\prime}$ in $\delta_{\mathrm{H}} 7.96(\mathrm{~d}$, $J 8.5 \mathrm{~Hz}$ ) with $\mathrm{H}-20$ and $\mathrm{H}-20$ ' in $\delta_{\mathrm{H}} 7.59(\mathrm{~d}, J 8.4 \mathrm{~Hz})$ of the described system AA'BB'.

In the compound $\mathbf{7} \mathbf{c}$ two-dimensional spectrum of direct correlation $\left({ }^{1} \mathrm{H},{ }^{13} \mathrm{C}-\mathrm{HSQC}\right)$, it was possible to unequivocally attribute the couplings between the signals of methylenic hydrogens of $\mathrm{H}-13\left(\delta_{\mathrm{H}} 4.16\right)$ with the carbon C-13 $\left(\delta_{\mathrm{H}} 63.4\right)$ and between the signal $\delta_{\mathrm{H}} 4.31$ referring the hydrogens $\mathrm{H}-16$ with the carbon $\mathrm{C}-16\left(\delta_{\mathrm{H}} 64.6\right)$, as well as the following couplings: olefinics $\left(\delta_{\mathrm{H}} / \delta_{\mathrm{C}}\right) 5.99(\mathrm{H}-2) / 119.7(\mathrm{C}-2), 7.35$ (H-3)/145.1 (C-3), 6.98 (H-4)/124.6 (C-4), $6.98(\mathrm{H}-5) / 140.4$ $(\mathrm{C}-5)$; aliphatics $\left(\delta_{\mathrm{H}} / \delta_{\mathrm{C}}\right) 6.05(\mathrm{H}-12) / 101.3(\mathrm{C}-12), 1.78$ (H-14)/24.8 (C-14), $1.78(\mathrm{H}-15) / 24.9(\mathrm{C}-15)$; and aromatics $\left(\delta_{\mathrm{H}} / \delta_{\mathrm{C}}\right) 7.21(\mathrm{H}-7) / 105.7(\mathrm{C}-7), 6.92(\mathrm{H}-10) / 108.7(\mathrm{C}-10)$, $6.98(\mathrm{H}-11) / 123.2$ (C-11), 7.96 (H-19, H-19')/130.9 (C-19, C-19'), 7.59 (H-20, H-20')/128.9 (C-19, C-19').

In the ${ }^{1} \mathrm{H}$ NMR spectrum of compound $\mathbf{7 k}$, signals are observed in the regions of $\delta_{\mathrm{H}} 8.54-5.98$, referring to the thirteen aromatic and olefinic hydrogens, and in $\delta_{\mathrm{H}} 6.04$, the singlet for the hydrogens of the methylenedioxy ring (H-12). In the region of $\delta_{\mathrm{H}} 4.22-4.16$, the presence of two triplets referring to the hydrogens $\mathrm{H}-13$ and $\mathrm{H}-16$ is seen, and in $\delta_{\mathrm{H}} 1.77-1.70$ the overlap of the signals referring to the hydrogens $\mathrm{H}-14$ and $\mathrm{H}-15$ is noted as well.

In the ${ }^{13} \mathrm{C}$ NMR spectra of the final compounds $\mathbf{7 j - 7} \mathbf{7 m}$, the presence of two very close carbonyls is noted, which is due to both being conjugated with an olefinic and aromatic segment. For unequivocally attributing the chemical displacements present in these compounds, the HMBC bidimensional spectrum was utilized.

In the HMBC experiment of compound $\mathbf{7 k}$ the carbon signal in $\delta_{\mathrm{H}} 166.2$ couples with the signals of $\mathrm{H}-2\left(\delta_{\mathrm{H}} 5.99\right)$, $\mathrm{H}-3\left(\delta_{\mathrm{H}} 7.36\right)$ and $\mathrm{H}-13\left(\delta_{\mathrm{H}} 4.16\right)$, showing that this signal corresponds to the carbonyl group of the piperinic segment (C-1). The signal in $\delta_{\mathrm{H}} 165.8$ couples with the signals of the hydrogens $\mathrm{H}-19\left(\delta_{\mathrm{H}} 7.78\right), \mathrm{H}-18\left(\delta_{\mathrm{H}} 6.89\right)$ and $\mathrm{H}-16$ $\left(\delta_{\mathrm{H}} 4.21\right)$, corresponding to the carbonyl (C-17).

In the bidimensional spectrum $\left({ }^{1} \mathrm{H},{ }^{1} \mathrm{H}-\mathrm{COSY}\right)$ of compound $7 \mathbf{k}$, correlations $\left({ }^{3} J\right)$ between the aliphatic hydrogens $\mathrm{H}-13\left(\delta_{\mathrm{H}} 4.16\right)$ with $\mathrm{H}-14\left(\delta_{\mathrm{H}} 1.75\right)$ are verified. The hydrogens H-14 couple with H-15 $\left(\delta_{\mathrm{H}} 1.75\right)$, H-15 with $\mathrm{H}-16\left(\delta_{\mathrm{H}} 4.21\right)$, and vice versa. Also in this spectrum, there can be verified important correlations between the aromatic hydrogens of the piperinic segment in the ortho position $\left({ }^{3} J\right)$ referring to the $\mathrm{H}-10\left(\delta_{\mathrm{H}} 6.91\right)$ with $\mathrm{H}-11$ $\left(\delta_{\mathrm{H}} 6.98\right)$ and in the meta position $\left({ }^{4} J\right)$ of $\mathrm{H}-11\left(\delta_{\mathrm{H}} 6.98\right)$ 
with H-7 $\left(\delta_{\mathrm{H}} 7.19\right)$. Similarly, correlations were noted between aromatic hydrogens of the other ester subunit aromatic ring in the meta position $\left({ }^{4} J\right)$ referring to the $\mathrm{H}-21$ $\left(\delta_{\mathrm{H}} 8.54\right)$ with $\mathrm{H}-23\left(\delta_{\mathrm{H}} 8.23\right)$, and the $\mathrm{H}-21\left(\delta_{\mathrm{H}} 8.54\right)$ with $\mathrm{H}-25\left(\delta_{\mathrm{H}} 8.19\right)$, the remainder in ortho position $\left({ }^{3} J\right)$ of $\mathrm{H}-23$ $\left(\delta_{\mathrm{H}} 8.23\right)$ with $\mathrm{H}-24\left(\delta_{\mathrm{H}} 7.69\right)$, of H-24 $\left(\delta_{\mathrm{H}} 7.69\right)$ with $\mathrm{H}-25$ $\left(\delta_{\mathrm{H}} 8.19\right)$, and vice versa.

The bidimensional spectrum of direct correlation $\left({ }^{1} \mathrm{H},{ }^{13} \mathrm{C}-\mathrm{HSQC}\right)$ made it possible to establish the following correlations: olefinics $\left(\delta_{\mathrm{H}} / \delta_{\mathrm{C}}\right): 5.99(\mathrm{H}-2) / 119.7(\mathrm{C}-2), 7.36$ (H-3)/145.1 (C-3), 6.98 (H-4)/124.6 (C-4), $6.98(\mathrm{H}-5) / 140.5$ (C-5), $6.84(\mathrm{H}-18) / 121.0$ (C-18), 7.78 (H-19)/142.0 $(\mathrm{C}-19)$; aliphatics $\left(\delta_{\mathrm{H}} / \delta_{\mathrm{C}}\right): 6.04(\mathrm{H}-12) / 101.4(\mathrm{C}-12)$, 4.16 (H-13)/63.9 (C-13), 1.75 (H-14)/24.9 (C-14), 1.75 $(\mathrm{H}-15) / 24.9(\mathrm{C}-15), 4.21(\mathrm{H}-16) / 63.4(\mathrm{C}-16)$ and aromatics $\left(\delta_{\mathrm{H}} / \delta_{\mathrm{C}}\right): 7.19(\mathrm{H}-21) / 105.7(\mathrm{C}-7), 6.91(\mathrm{H}-10) / 108.5(\mathrm{C}-10)$, 6.98 (H-11)/123.2 (C-11), 8.54 (H-21)/123.0 (C-21), 8.22 (H-23)/124.5 (C-23), 7.69 (H-24)/130.3 (C-24), 8.19 (H-25)/134.1 (C-25).

\section{In silico study}

One of the most common theoretical approaches of pharmacokinetic parameters in the in silico study is the Lipinski's rule of five. ${ }^{20}$ Lipinski's rule applies a set of parameters capable of identifying compounds with absorption and permeability issues, aiming to evaluate the theoretical potential that a molecule has to be absorbed orally. It was identified that, for good absorption and permeation, the drug must meet at least three of the following four criteria: hydrogen bond acceptors $(\mathrm{HBA}) \leq 10$, hydrogen bond donors $(\mathrm{HBD}) \leq 5$, molecular weight $(\mathrm{MW}) \leq 500$ and lipophilicity $(\log \mathrm{P}) \leq 5$.

In this work, it was decided to investigate the theoretical potential of the new piperine derivatives (7a-7o) through the in silico approach of the parameters from Lipinski's rule of five,,$^{20,21}$ together with the following parameters: topological polar surface area (TPSA), theoretical absorption percentage (ABS), aqueous solubility $(\log S)$, drug-likeness and drug-score.

Results of the in silico study for piperine-derived diesters are presented in Table 1.

According to the results shown in Table 1, only compounds $\mathbf{7 a}, \mathbf{7 b}, \mathbf{7 g}, \mathbf{7 k}, \mathbf{7 n}$ and $\mathbf{7 o}$ satisfy the rule of Lipinski with no violation, whereas compounds $\mathbf{7 c}, \mathbf{7 d}$, $\mathbf{7 f}, 7 \mathbf{i}, 7 \mathbf{j}, \mathbf{7 l}, \mathbf{7 m}$ violated only one of the parameters. As Lipinski's rule admits one violation, it is posited that these compounds should present good permeability in the cell membrane and good absorption after oral administration. The compounds $\mathbf{7 e}$ and $\mathbf{7 h}$ violated two parameters, thus suggesting insufficient oral bioavailability according to the rule. Molecules with TPSA $\leq 140 \AA^{2}$ tend to have better oral bioavailability and higher permeation velocity. ${ }^{22}$ The results showed that all compounds, with the exception of $7 \mathbf{h}$, presented TPSA values between 71.06 and $116.08 \AA^{2}$, resulting in a high percentage of absorption (68.70-84.48\%). The compound $7 \mathbf{h}\left(\mathrm{TPSA}=162.7 \AA^{2}\right)$ was classified with an average absorption $(52.87 \%)$.

Table 1. In silico study of the new piperine derivatives (7a-7o)

\begin{tabular}{|c|c|c|c|c|c|c|c|c|c|c|}
\hline \multirow{2}{*}{ Compound } & \multicolumn{5}{|c|}{ Lipinski's parameter } & \multirow{2}{*}{ TPSA / $\AA^{2}$} & \multirow{2}{*}{ ABS $/ \%$} & \multirow{2}{*}{$\log S$} & \multirow{2}{*}{ Drug likeness } & \multirow{2}{*}{ Drug score } \\
\hline & HBA & HBD & MW & $\operatorname{clog} \mathrm{P}$ & nViol & & & & & \\
\hline $7 \mathbf{a}$ & 6 & 0 & 332.35 & 3.54 & 0 & 71.06 & 84.484 & -3.89 & -6.49 & 0.18 \\
\hline $7 b$ & 6 & 0 & 394.42 & 4.99 & 0 & 71.06 & 84.484 & -5.06 & -5.59 & 0.09 \\
\hline $7 c$ & 6 & 0 & 428.87 & 5.59 & 1 & 71.06 & 84.484 & -5.80 & -3.29 & 0.09 \\
\hline $7 d$ & 6 & 0 & 473.32 & 5.71 & 1 & 71.06 & 84.484 & -5.71 & -8.95 & 0.08 \\
\hline $7 e$ & 6 & 0 & 520.32 & 5.42 & 2 & 71.06 & 84.484 & -6.08 & -5.25 & 0.08 \\
\hline $7 f$ & 6 & 0 & 408.45 & 5.33 & 1 & 71.06 & 84.484 & -5.41 & -6.78 & 0.10 \\
\hline $7 \mathrm{~g}$ & 9 & 0 & 439.42 & 4.06 & 0 & 116.80 & 68.704 & -5.52 & -20.54 & 0.12 \\
\hline $7 \mathrm{~h}$ & 12 & 0 & 484.42 & 3.14 & 2 & 162.70 & 52.869 & -5.98 & -20.64 & 0.14 \\
\hline $7 \mathbf{i}$ & 9 & 0 & 473.87 & 4.67 & 1 & 116.80 & 68.704 & -6.26 & -14.25 & 0.11 \\
\hline $7 \mathbf{j}$ & 6 & 0 & 420.46 & 5.32 & 1 & 71.06 & 84.484 & -5.43 & -7.86 & 0.08 \\
\hline $7 \mathbf{k}$ & 9 & 0 & 465.46 & 4.39 & 0 & 116.80 & 68.704 & -5.89 & -11.72 & 0.13 \\
\hline 71 & 6 & 0 & 488.46 & 6.16 & 1 & 71.06 & 84.484 & -6.21 & -13.84 & 0.09 \\
\hline $7 m$ & 6 & 0 & 426.46 & 5.18 & 1 & 99.30 & 74.742 & -5.44 & -4.94 & 0.13 \\
\hline $7 n$ & 7 & 0 & 438.48 & 4.91 & 0 & 80.29 & 81.300 & -5.05 & -7.20 & 0.14 \\
\hline 70 & 9 & 0 & 477.47 & 3.97 & 0 & 108.40 & 71.602 & -4.83 & -15.80 & 0.16 \\
\hline
\end{tabular}

HBA: hydrogen bond acceptor; HBD: hydrogen bond donor; MW: molecular weight; clogP: octanol/water partition coefficient based on Molinspiration; nViol: number of violations; TPSA: topological surface area; ABS: adsorption percentage; log S: solubility. 
Most commercial medicines have $\log \mathrm{S}>-4.00$ (OSIRIS Property Explorer). ${ }^{23}$ In the results, however, only compound 7a had $\log \mathrm{S}>-4.00$. For drug-likeness, the compounds presented values in the range of -20.64 to -3.29. Regarding the results for the drug-score study (which combines parameters of lipophilicity, aqueous solubility, molecular mass, drug-likeness and toxicity risk), the values ranged from 0.08 to 0.18 , with compound $7 \mathbf{a}$ having the highest value.

\section{Antimicrobial study}

The results of the compounds 7a-7o in vitro antimicrobial activity assays are shown in Table 2.

As shown in Table 2, among the fifteen tested compounds, only the substances $\mathbf{7 b}, \mathbf{7 d}, \mathbf{7 e}, \mathbf{7 g}, \mathbf{7 h}, \mathbf{7 i}$ and 71 did not show activity against the selected microorganisms at the evaluated concentrations. The substance $\mathbf{7} \mathbf{j}$ showed activity only over Candida yeasts with a minimum inhibitory concentration (MIC) of $1024 \mu \mathrm{g} \mathrm{mL}{ }^{-1}$ against all tested yeasts. For $50 \%$ of the species, the substance 7o presented an MIC of $512 \mu \mathrm{g} \mathrm{mL} \mathrm{m}^{-1}$. The compounds $7 \mathbf{a}$, $7 \mathrm{c}$ and $\mathbf{7 m}$ showed inhibitory activity against $60 \%$ of the microorganisms with an MIC of $256 \mu \mathrm{g} \mathrm{mL} \mathrm{m}^{-1}$. Substances $\mathbf{7 m}$ and $\mathbf{7 n}$ presented an MIC of $1024 \mu \mathrm{g} \mathrm{mL} \mathrm{m}^{-1}$ for $70 \%$ of the microorganisms (yeasts and filamentous fungi). The substance 7f presented an MIC of $256 \mu \mathrm{g} \mathrm{mL}^{-1}$ against $80 \%$ of the microorganisms. It is noteworthy that this substance inhibited $100 \%$ of the fungal species, attesting great antifungal potential due to its broad action.

No substance was able to inhibit the microbial growth of the tested bacterial species. However, the fact that these substances did not present antibacterial activity can still be considered a positive aspect, since a possible antifungal treatment with these molecules would most likely not put at risk the integrity of native microbiota, which is beneficial to the host. ${ }^{24}$

The results of antimicrobial activity of the final compounds (7a-7o) showed that the compounds that had electron-donating groups $(\mathbf{7 c}, \mathbf{7 f}, \mathbf{7 n})$ were active against most microorganisms. The compounds $\mathbf{7 d}$ and $\mathbf{7 e}$ that presented donor groups, albeit voluminous $(\mathrm{Br}$ and $\mathrm{I}$, respectively), were inactive.

The compounds which possessed substituting electronremoving groups $(\mathbf{7 g}, \mathbf{7 h}$ and $\mathbf{7 i}$ ) were inactive against the tested microorganisms. As to the compounds $\mathbf{7 j - 7} \mathbf{7 m}$, which

Table 2. Minimum inhibitory concentration (MIC) of piperine derivatives 7a-7o against bacterial and fungal strains

\begin{tabular}{|c|c|c|c|c|c|c|c|c|c|c|}
\hline \multirow{3}{*}{ Compound } & \multicolumn{10}{|c|}{$\mathrm{MIC} /\left(\mu \mathrm{g} \mathrm{mL}^{-1}\right)$} \\
\hline & \multicolumn{2}{|c|}{ Bacteria } & \multicolumn{4}{|c|}{ Yeast } & \multicolumn{4}{|c|}{ Filamentous fungi } \\
\hline & $\begin{array}{c}\text { S. aureus } \\
\text { ATCC-25923 }\end{array}$ & $\begin{array}{l}\text { P. aeruginosa } \\
\text { ATCC- } 25853\end{array}$ & $\begin{array}{c}\text { C. albicans } \\
\text { ATCC-60193 }\end{array}$ & $\begin{array}{l}\text { C. albicans } \\
\text { LM-92 }\end{array}$ & $\begin{array}{c}\text { C. tropicalis } \\
\text { ATCC-13803 }\end{array}$ & $\begin{array}{l}\text { C. tropicalis } \\
\text { LM-18 }\end{array}$ & $\begin{array}{l}\text { A. flavus } \\
\text { LM-714 }\end{array}$ & $\begin{array}{l}\text { A. niger } \\
\text { LM-108 }\end{array}$ & $\begin{array}{l}\text { A. fumigatus } \\
\text { ATCC-40640 }\end{array}$ & $\begin{array}{l}\text { A. fumigatus } \\
\text { IPP-210 }\end{array}$ \\
\hline $7 \mathbf{a}$ & + & + & 256 & 256 & 1024 & 1024 & + & 256 & 256 & + \\
\hline $7 b$ & + & + & + & + & + & + & + & + & + & + \\
\hline $7 \mathrm{c}$ & + & + & 256 & 1024 & 1024 & 256 & + & 256 & 1024 & + \\
\hline $7 d$ & + & + & + & + & + & + & + & + & + & + \\
\hline $7 e$ & + & + & + & + & + & + & + & + & + & + \\
\hline $7 f$ & + & + & 256 & 1024 & 1024 & 512 & 512 & 256 & 256 & 256 \\
\hline $7 \mathrm{~g}$ & + & + & + & + & + & + & + & + & + & + \\
\hline $7 \mathrm{~h}$ & + & + & + & + & + & + & + & + & + & + \\
\hline $7 \mathbf{i}$ & + & + & + & + & + & + & + & + & + & + \\
\hline $7 \mathbf{j}$ & + & + & 1024 & 1024 & 1024 & 1024 & + & + & + & + \\
\hline $7 \mathrm{k}$ & + & + & 1024 & 256 & 1024 & 1024 & 1024 & 512 & 512 & + \\
\hline 71 & + & + & + & + & + & + & + & + & + & + \\
\hline $7 \mathrm{~m}$ & + & + & 1024 & 1024 & 256 & 256 & + & 256 & 256 & + \\
\hline $7 n$ & + & + & 1024 & 1024 & 1024 & 1024 & 1024 & 256 & 256 & + \\
\hline 70 & + & + & 256 & 512 & 512 & 1024 & + & + & 1024 & + \\
\hline Culture media & - & - & - & - & - & - & - & - & - & - \\
\hline Microorganisms & + & + & + & + & + & + & + & + & + & + \\
\hline Amphotericin B & a & a & - & - & - & - & - & - & - & - \\
\hline Gentamicin & - & - & a & a & a & a & a & a & a & $*$ \\
\hline
\end{tabular}

${ }^{a}$ Not employed. +: presence of microbial growth; -: absence of microbial growth. 
have in their structure an additional $\alpha, \beta$-unsaturated bond, all but compound $\mathbf{7 l}$ were active against most of the tested strains.

It is noteworthy that to better understand the relationship between the results observed in the in vitro study and the physicochemical properties of synthesized compounds, a structure-activity relationship (SAR) study is necessary.

\section{Conclusions}

In this work, twenty-two novel compounds were synthesized: seven new $\delta$-chloro-esters and fifteen new piperine-derived diesters. Their structures were elucidated by infrared spectroscopic techniques, ${ }^{1} \mathrm{H}$ and ${ }^{13} \mathrm{C}$ NMR, COSY, $\mathrm{HMBC}$ and HSQC. In the in silico study, only compounds 7e and $\mathbf{7 h}$ violated two of Lipinski's parameters, hence it is inferred that these do not possess good oral bioavailability. The in vitro antimicrobial assays showed that the synthesized compounds were not active against the bacterial species tested, displaying only antifungal activity, especially against yeast fungi. The compounds $\mathbf{7 a}, \mathbf{7 c}$ and $\mathbf{7 m}$ were active against $60 \%$ of the strains, with an MIC of $256 \mu \mathrm{g} \mathrm{mL} \mathrm{m}^{-1}$. The compounds $\mathbf{7 m}$ and $\mathbf{7 n}$ presented an MIC of $1024 \mu \mathrm{g} \mathrm{mL}$ against $70 \%$ of the tested microorganisms. The compound $7 \mathbf{f}$ showed broad antimicrobial activity, inhibiting $80 \%$ of the microorganisms with an MIC of $256 \mu \mathrm{g} \mathrm{mL}{ }^{-1}$. It is then inferred that these findings are of significant relevance in presenting new molecules with antifungal activity, thus encouraging further research involving these substances against infections of difficult treatment.

\section{Experimental}

\section{Chemistry}

The piperine (1) was extracted from black pepper (Piper nigrum L.) according to the methods described by Ikan. ${ }^{18}$ The other reagents and solvents used were acquired from Sigma-Aldrich (São Paulo, Brazil) and used without further purification. The structures of the compounds were confirmed by infrared spectra obtained in a FTIR Shimadzu spectrometer, IR Prestige-21 model, with an accessory ATR (attenuated total reflection). The ${ }^{1} \mathrm{H},{ }^{13} \mathrm{C}$ NMR, and 2D NMR (COSY, HSQC and HMBC) spectra were obtained in a Varian spectrometer, Mercury model (400 and $500 \mathrm{MHz}$ for ${ }^{1} \mathrm{H}$, and 101 and $126 \mathrm{MHz}$ for ${ }^{13} \mathrm{C}$ ), and the fusion range on a heating plate MQAPF-3. For samples solubilization, deuterated dimethyl sulfoxide (DMSO- $d_{6}$ ) and deuterated chloroform $\left(\mathrm{CDCl}_{3}\right)$ were used. Chemical deviations $(\delta)$ were measured in parts per million $(\mathrm{ppm})$ and coupling constants $(J)$ in hertz $(\mathrm{Hz})$.
Isolation of 1-piperoyl-piperidine (piperine) (1)

In a Soxhlet apparatus, $100 \mathrm{~g}$ of black pepper were added with $1000 \mathrm{~mL}$ of ethanol $95 \%$. The system was kept in reflux for approximately $10 \mathrm{~h}$. After concentrating the extract in the rotary-evaporator, $100 \mathrm{~mL}$ of an alcoholic solution of $10 \% \mathrm{KOH}$ was added, and then the precipitated material was filtered. A small amount of water was added to the alcoholic solution until the medium became turbid. After $72 \mathrm{~h}$ at rest, the formed precipitate was filtered, ${ }^{18}$ and $3.5 \mathrm{~g}$ of piperine (3.5\% yield) was obtained with the following characteristics. Molecular weight (MW) $285.34 \mathrm{~g} \mathrm{~mol}^{-1}$; $\mathrm{mp}$ 126-128 ${ }^{\circ} \mathrm{C}$ (lit.. ${ }^{25} 129-130{ }^{\circ} \mathrm{C}$ ); IR (ATR) v / cm ${ }^{-1} 2939$ $\left(\mathrm{C}-\mathrm{H}_{\mathrm{Ar}}\right), 1631(\mathrm{C}=\mathrm{O}), 1581-1442\left(\mathrm{C}=\mathrm{C}_{\mathrm{Ar}}\right), 1249(\mathrm{C}-\mathrm{O}-\mathrm{C})$, $930\left(\mathrm{C}-\mathrm{H}_{\mathrm{Ar}}\right) ;{ }^{1} \mathrm{H}$ NMR $\left(400 \mathrm{MHz}, \mathrm{CDCl}_{3}\right) \delta 7.40$ (ddd, $J 14.7,8.9,1.2 \mathrm{~Hz}, 1 \mathrm{H}), 6.95(\mathrm{~s}, J 1.6 \mathrm{~Hz}, 1 \mathrm{H}), 6.86$ (dd, $J$ 8.1, $1.7 \mathrm{~Hz}, 1 \mathrm{H}), 6.76-6.66(\mathrm{~m}, 3 \mathrm{H}), 6.41(\mathrm{~d}, J 14.6 \mathrm{~Hz}$, $1 \mathrm{H}), 5.94(\mathrm{~s}, 2 \mathrm{H}), 3.60-3.48(\mathrm{~m}, 4 \mathrm{H}), 1.64(\mathrm{~m}, 2 \mathrm{H}, \mathrm{H}-15)$, $1.59-1.53(\mathrm{~m}, 4 \mathrm{H}) ;{ }^{13} \mathrm{C}$ NMR (101 MHz, $\left.\mathrm{CDCl}_{3}\right) \delta 165.5$, $148.2,148.1,142.8,138.4,130.9,125.3,122.5,119.7$, 108.4, 105.6, 101.3, 46.3, 26.1, 24.6.

Preparation of $(2 E, 4 E)-5$-(benzo[d][1,3]dioxol-5-yl)penta2,4-dienoic acid (piperic acid) (2)

The mixture of $2.20 \mathrm{~g}(7.72 \mathrm{mmol})$ of piperine and $22 \mathrm{~mL}$ of $20 \% \mathrm{KOH}$ (ethanolic solution) was subjected to reflux and agitation for $20 \mathrm{~h}$. After the end of reaction, the mixture was filtered, washed with ethanol and dried. The precipitate formed was solubilized in water and acidified with $\mathrm{HCl}$ solution $10 \%$ down to $\mathrm{pH} 3$. The precipitate formed with a yellowish coloration was filtered, washed with water, dried and recrystallized in ethanol. ${ }^{18}$ Yield: 94.5\% (1.67 g); MW $218.21 \mathrm{~g} \mathrm{~mol}^{-1}$; mp 217-218 ${ }^{\circ} \mathrm{C}$ (lit.: ${ }^{18}$ 216-217 ${ }^{\circ} \mathrm{C}$ ); IR (ATR) $v / \mathrm{cm}^{-1} 3448(\mathrm{O}-\mathrm{H})$, $2922\left(\mathrm{C}-\mathrm{H}_{\text {Aliph }}\right), 1676(\mathrm{C}=\mathrm{O}), 1604-1419\left(\mathrm{C}=\mathrm{C}_{\mathrm{Ar}}\right), 1255$ $(\mathrm{C}-\mathrm{O}-\mathrm{C}), 927\left(\mathrm{C}-\mathrm{H}_{\mathrm{Ar}}\right) ;{ }^{1} \mathrm{H}$ NMR $\left(400 \mathrm{MHz}, \mathrm{CDCl}_{3}\right)$ $\delta 12.20(\mathrm{~s}, 1 \mathrm{H}, \mathrm{O}-\mathrm{H}), 7.36-7.26(\mathrm{~m}, 1 \mathrm{H}), 7.23(\mathrm{~s}, 1 \mathrm{H})$, 7.03-6.89 (m, 4H), 6.05 (s, 2H), 5.93 (d, J $15.2 \mathrm{~Hz}, 1 \mathrm{H})$; ${ }^{13} \mathrm{C}$ NMR $\left(101 \mathrm{MHz}, \mathrm{CDCl}_{3}\right) \delta 168.1,148.5,148.4,145.1$, 140.2, 130.9, 125.3, 123.5, 121.5, 108.4, 106.1, 101.8 .

Preparation of piperate of potassium (3)

An ethanolic solution of $\mathrm{KOH}(10 \mathrm{mmol})$ was added to a mixture of ethanol and piperic acid $(10 \mathrm{mmol})$. The reaction mixture was constantly agitated at room temperature for $1 \mathrm{~h}$. The solid obtained was filtered and dried. Yield: 93\%; MW $256.30 \mathrm{~g} \mathrm{~mol}^{-1}$; IR (ATR) $\mathrm{V} / \mathrm{cm}^{-1} 3022\left(\mathrm{C}-\mathrm{H}_{\mathrm{Ar}}\right), 2908$ $\left(\mathrm{C}-\mathrm{H}_{\text {Aliph }}\right), 1550(\mathrm{C}=\mathrm{O}), 1500-1448\left(\mathrm{C}=\mathrm{C}_{\mathrm{Ar}}\right), 1255(\mathrm{C}-\mathrm{O})$. 
General procedure for acid chlorides (5a-5o)

In a $50 \mathrm{~mL}$ flask coupled with a condenser and drying tube $\left(\mathrm{CaCl}_{2}\right), 2.0 \mathrm{~mL}$ of thionyl chloride $\left(\mathrm{SOCl}_{2}\right)$ were quickly added to $15 \mathrm{mmol}$ of the corresponding carboxylic acid (4a-4o) and catalytic two drops of dimethylformamide (DMF). The mixture was maintained in reflux and agitation; the reaction time ranged 2-6 h. The excess $\mathrm{SOCl}_{2}$ was then rotary-evaporated and washed with dichloromethane. Thus, it was obtained the acid chlorides (5a-5o) used in situ in the next stage of synthesis.

\section{General procedure for the $\delta$-chloro-esters (6a-6o)}

In a $25 \mathrm{~mL}$ flask, $10 \mathrm{~mL}$ of THF were added, together with $0.0136 \mathrm{~g}$ of $\mathrm{ZnCl}_{2}(0.1 \mathrm{mmol})$ and $10 \mathrm{mmol}$ of the respective acid chlorides (5a-5o). The mixture was stirred and heated to a temperature of $75^{\circ} \mathrm{C}$ and accompanied by thin layer chromatography (TLC). The mixture was subsequently cooled and the solvent rotary-evaporated. The residue was dissolved in dichloromethane $(30 \mathrm{~mL})$, transferred to a separation funnel and washed with distilled water $(3 \times 30 \mathrm{~mL})$. The organic phase was separated and washed with saturated sodium bicarbonate solution $(3 \times 30 \mathrm{~mL})$, distilled water $(3 \times 30 \mathrm{~mL})$ and sodium chloride solution $(3 \times 30 \mathrm{~mL})$, alternating them during the process, until a $\mathrm{pH}$ close to 7 was verified, in order to certify the absence of acid or base. The organic phase was treated with anhydrous $\mathrm{Na}_{2} \mathrm{SO}_{4}$ to eliminate water remnants, and the solvent then rotoevaporated. The product was purified in a chromatographic column using hexane/dichloromethane as eluent. ${ }^{19}$

\section{4-Chlorobutyl acetate (6a)}

Colorless liquid; yield: 90\%; MW $150.60 \mathrm{~g} \mathrm{~mol}^{-1}$; IR (ATR) $v / \mathrm{cm}^{-1} 1735(\mathrm{C}=\mathrm{O}), 1234,1041(\mathrm{C}-\mathrm{O}), 1365$, $650(\mathrm{C}-\mathrm{Cl}) ;{ }^{1} \mathrm{H}$ NMR $\left(400 \mathrm{MHz}, \mathrm{CDCl}_{3}\right) \delta 4.07(\mathrm{t}, 2 \mathrm{H}$, $\left.\mathrm{OC}_{2} \underline{\mathrm{Aliph}}_{2}\right), 3.54$ (t, $\left.2 \mathrm{H}, \mathrm{C}_{2} \mathrm{Cl}\right), 2.02$ (s, 3H, $\underline{\mathrm{H}}_{3} \mathrm{C}=\mathrm{O}$ ), $2.02\left(\mathrm{~m}, 4 \mathrm{H}, \mathrm{CH}_{2} \underline{\mathrm{CH}}_{2 \mathrm{Aliph}}\right) ;{ }^{13} \mathrm{C} \mathrm{NMR}\left(101 \mathrm{MHz}, \mathrm{CDCl}_{3}\right)$ $\delta$ 171.1, 63.6, 44.5, 29.2, 26.1, 20.9.

\section{4-Chlorobutyl benzoate (6b)}

Colorless liquid; yield: 92\%; MW $212.68 \mathrm{~g} \mathrm{~mol}^{-1}$; IR (ATR) $v / \mathrm{cm}^{-1} 1716(\mathrm{C}=\mathrm{O}), 1271,1070(\mathrm{C}-\mathrm{O}), 1112,709$ $(\mathrm{C}-\mathrm{Cl}) ;{ }^{1} \mathrm{H}$ NMR $\left(400 \mathrm{MHz}, \mathrm{CDCl}_{3}\right) \delta 8.03$ (dd, J 8.4, $\left.1.4 \mathrm{~Hz}, 2 \mathrm{H}, \underline{\mathrm{C}}_{\mathrm{Ar}}\right), 7.55\left(\mathrm{t}, J 7.4 \mathrm{~Hz}, 1 \mathrm{H}, \mathrm{C}_{\mathrm{Ar}}\right), 7.43$ (d, $\left.2 \mathrm{H}, \mathrm{C}_{\mathrm{Ar}}\right), 4.35$ (t, $\left.2 \mathrm{H}, \mathrm{OC}_{2 \mathrm{Aliph}}\right), 3.60$ (t, $\left.2 \mathrm{H}, \mathrm{C}_{2} \mathrm{Cl}\right)$, 2.00-1.87 (m, 4H, $\left.\underline{\mathrm{H}}_{2} \mathrm{C}_{\mathrm{H}_{2 \mathrm{Aliph}}}\right) ;{ }^{13} \mathrm{C} \mathrm{NMR} \mathrm{(101} \mathrm{MHz,}$ $\left.\mathrm{CDCl}_{3}\right) \delta 166.5,133.0,130.2,129.5,128.4,64.1,44.5$, 29.3, 26.2.
4-Chlorobutyl 4-chlorobenzoate (6c)

Colorless liquid; yield: 85\%; MW $247.12 \mathrm{~g} \mathrm{~mol}^{-1}$; IR (ATR) $v / \mathrm{cm}^{-1} 1718(\mathrm{C}=\mathrm{O}), 1269,1014(\mathrm{C}-\mathrm{O}), 1116,759$ $(\mathrm{C}-\mathrm{Cl}), 1089\left(\mathrm{C}_{\mathrm{Ar}}-\mathrm{Cl}\right) ;{ }^{1} \mathrm{H}$ NMR $\left(400 \mathrm{MHz}, \mathrm{CDCl}_{3}\right) \delta 7.94$ (dd, J $\left.8.8 \mathrm{~Hz}, 2 \mathrm{H}, \mathrm{C}_{\mathrm{Ar}}\right), 7.38\left(\mathrm{dd}, J 8.8 \mathrm{~Hz}, 2 \mathrm{H}, \mathrm{C}_{\mathrm{Ar}}\right)$, 4.33 (t, $\left.2 \mathrm{H}, \mathrm{OC}_{2 \mathrm{Hliph}}\right), 3.58\left(\mathrm{t}, 2 \mathrm{H}, \mathrm{CH}_{2} \mathrm{Cl}\right), 2.00-1.78(\mathrm{~m}$, $\left.4 \mathrm{H}, \mathrm{C}_{2} \underline{\mathrm{CH}}_{2 \mathrm{Aliph}}\right) ;{ }^{13} \mathrm{C} \mathrm{NMR}\left(101 \mathrm{MHz}, \mathrm{CDCl}_{3}\right) \delta$ 166.6, 139.4, 130.9, 128.7, 128.7, 64.4, 44.4, 29.2, 26.1.

\section{4-Chlorobutyl 4-bromobenzoate (6d)}

Colorless liquid; yield: $80 \%$; MW $291.57 \mathrm{~g} \mathrm{~mol}^{-1}$; IR (ATR) $\mathrm{v} / \mathrm{cm}^{-1} 1718(\mathrm{C}=\mathrm{O}), 1267,1010(\mathrm{C}-\mathrm{O}), 1114,756$ $(\mathrm{C}-\mathrm{Cl}), 1010\left(\mathrm{C}_{\mathrm{Ar}}-\mathrm{Br}\right) ;{ }^{1} \mathrm{H} \mathrm{NMR}\left(400 \mathrm{MHz}, \mathrm{CDCl}_{3}\right) \delta 7.88$ $\left(\mathrm{dd}, J 8.7 \mathrm{~Hz}, 2 \mathrm{H}, \underline{\mathrm{CH}}_{\mathrm{Ar}}\right), 7.59\left(\mathrm{dd}, J 10.9 \mathrm{~Hz}, 2 \mathrm{H}, \mathrm{C}_{\mathrm{Ar}}\right)$, 4.34 (t, $\left.2 \mathrm{H}, \mathrm{OCH}_{2 \mathrm{Aliph}}\right), 3.59$ (t, $\left.2 \mathrm{H}, \mathrm{CH}_{2} \mathrm{Cl}\right), 1.96-1.89$ (m, $\left.4 \mathrm{H}, \mathrm{CH}_{2} \underline{\mathrm{CH}}_{2 \text { Aliph }}\right) ;{ }^{13} \mathrm{C}$ NMR (101 MHz, $\left.\mathrm{CDCl}_{3}\right) \delta 165.8$, $131.8,131.1,129.2,128.1,64.4,44.5,29.3,26.2$.

\section{4-Chlorobutyl 4-iodobenzoate (6e)}

Colorless liquid; yield: 74\%; MW $338.57 \mathrm{~g} \mathrm{~mol}^{-1}$; IR (ATR) $\mathrm{v} / \mathrm{cm}^{-1} 1716(\mathrm{C}=\mathrm{O}), 1265,1101(\mathrm{C}-\mathrm{O}), 1114,752$ $(\mathrm{C}-\mathrm{Cl}) ;{ }^{1} \mathrm{H}$ NMR $\left(400 \mathrm{MHz}, \mathrm{CDCl}_{3}\right) \delta 7.80(\mathrm{~d}, J 8.6 \mathrm{~Hz}$, $\left.2 \mathrm{H}, \mathrm{CH}_{\mathrm{Ar}}\right), 7.73\left(\mathrm{~d}, J 8.6 \mathrm{~Hz}, 2 \mathrm{H}, \mathrm{CH}_{\mathrm{Ar}}\right), 4.34(\mathrm{t}, 2 \mathrm{H}$, OC $\left.\underline{\mathrm{H}}_{2 \mathrm{Aliph}}\right), 3.60$ (t, 2H, $\underline{\mathrm{H}}_{2} \mathrm{Cl}$ ), 2.00-1.84 (m, $\underline{\mathrm{CH}}_{2} \mathrm{C}_{2 \mathrm{Hliph}}$ ); ${ }^{13} \mathrm{C} \mathrm{NMR}\left(101 \mathrm{MHz}, \mathrm{CDCl}_{3}\right) \delta 166.1,137.8,131.1,129.7$, $100.8,64.5,44.5,29.3,26.2$.

\section{4-Chlorobutyl 4-methylbenzoate (6f)}

Colorless liquid; yield: $83 \%$; MW $226.70 \mathrm{~g} \mathrm{~mol}^{-1}$; IR (ATR) $v / \mathrm{cm}^{-1} 1712$ (C=O), 1271, 1107 (C-O), 1176, 752 $(\mathrm{C}-\mathrm{Cl}) ;{ }^{1} \mathrm{H} \mathrm{NMR}\left(400 \mathrm{MHz}, \mathrm{CDCl}_{3}\right) \delta 7.92(\mathrm{dd}, J 8.1 \mathrm{~Hz}$, $\left.2 \mathrm{H}, \mathrm{C}_{\mathrm{Ar}}\right), 7.23\left(\mathrm{dd}, J 7.9 \mathrm{~Hz}, 2 \mathrm{H}, \mathrm{CH}_{\mathrm{Ar}}\right), 4.34(\mathrm{t}, 2 \mathrm{H}$, $\left.\mathrm{OC}_{2} \underline{\mathrm{Aliph}}_{2}\right), 3.61$ (t, $2 \mathrm{H}, \mathrm{CH}_{2} \mathrm{Cl}$ ), 2.40 (s, 3H, $\underline{\mathrm{H}}_{3} \mathrm{C}_{\mathrm{Ar}}$ ), 1.94 (m, $\left.4 \mathrm{H}, \underline{\mathrm{CH}}_{2} \underline{\mathrm{CH}}_{2 \mathrm{Aliph}}\right) ;{ }^{13} \mathrm{C} \mathrm{NMR}\left(101 \mathrm{MHz}, \mathrm{CDCl}_{3}\right) \delta 166.7$, 143.7, 129.6, 129.2, 127.5, 64.0, 44.6, 29.4, 26.3, 21.7.

\section{4-Chlorobutyl 4-nitrobenzoate (6g)}

Yellow liquid; yield: 90\%; MW $257.67 \mathrm{~g} \mathrm{~mol}^{-1}$; IR (ATR) $\mathrm{v} / \mathrm{cm}^{-1} 1722(\mathrm{C}=\mathrm{O}), 1271,1103(\mathrm{C}-\mathrm{O}), 1525,1348(\mathrm{~N}=\mathrm{O})$, 1116, $717(\mathrm{C}-\mathrm{Cl}) ;{ }^{1} \mathrm{H}$ NMR $\left(500 \mathrm{MHz}, \mathrm{CDCl}_{3}\right) \delta 8.26(\mathrm{dd}$, $\left.J 9.0 \mathrm{~Hz}, 2 \mathrm{H}, \mathrm{C}_{\mathrm{Ar}}\right), 8.18\left(\mathrm{dd}, J 9.0 \mathrm{~Hz}, 2 \mathrm{H}, \mathrm{C}_{\mathrm{Ar}}\right), 4.40$ (t, $\left.2 \mathrm{H}, \mathrm{OCH}_{2 \mathrm{Aliph}}\right), 3.60$ (t, $\left.2 \mathrm{H}, \mathrm{CH}_{2} \mathrm{Cl}\right), 2.06-1.82$ (m, 4H, $\left.\mathrm{C}_{2} \underline{\mathrm{CH}}_{2 \text { Aliph }}\right) ;{ }^{13} \mathrm{C} \mathrm{NMR}\left(126 \mathrm{MHz}, \mathrm{CDCl}_{3}\right) \delta 164.6,150.6$, 135.6, 130.7, 123.6, 65.1, 44.4, 29.2, 26.1.

\section{4-Chlorobutyl 3,5-dinitrobenzoate (6h)}

Pale yellow solid; yield: 92\%; MW $302.67 \mathrm{~g} \mathrm{~mol}^{-1}$; mp 39-40 ${ }^{\circ} \mathrm{C}$; IR (ATR) v / cm $\mathrm{cm}^{-1} 1724(\mathrm{C}=\mathrm{O}), 1271,1076$ (C-O), 1548, $1340(\mathrm{~N}=\mathrm{O}), 1164,717(\mathrm{C}-\mathrm{Cl}) ;{ }^{1} \mathrm{H}$ NMR $\left(400 \mathrm{MHz} \mathrm{CDCl}_{3}\right) \delta 9.20\left(\mathrm{~s}, J 2.2 \mathrm{~Hz}, 1 \mathrm{H}, \mathrm{CH}_{\mathrm{Ar}}\right), 9.13$ (d, J $\left.1.7 \mathrm{~Hz}, 2 \mathrm{H}, \mathrm{C}_{\mathrm{Ar}}\right), 4.50\left(\mathrm{t}, 2 \mathrm{H}, \mathrm{OC}_{2} \underline{\mathrm{H}}_{2 \mathrm{iph}}\right), 3.63$ (t, 
2H, $\mathrm{CH}_{2} \mathrm{Cl}$ ), 2.10-1.89 (m, 4H, $\mathrm{C}_{2} \mathrm{C}_{2 \text { Aliph }}$ ); ${ }^{13} \mathrm{C} \mathrm{NMR}$ $\left(101 \mathrm{MHz}, \mathrm{CDCl}_{3}\right) \delta 162.5,148.7,133.9,129.4,122.5$, $66.2,44.3,29.0,29.0,26.0$.

\section{4-Chlorobutyl 4-chloro-3-nitrobenzoate (6i)}

Yellow liquid; yield: 79\%; MW $292.12 \mathrm{~g} \mathrm{~mol}^{-1}$; IR (ATR) $v / \mathrm{cm}^{-1} 1722(\mathrm{C}=\mathrm{O}), 1280,1111(\mathrm{C}-\mathrm{O}), 1537$, $1352(\mathrm{~N}=\mathrm{O}), 1153,746(\mathrm{C}-\mathrm{Cl}) ;{ }^{1} \mathrm{H}$ NMR $(400 \mathrm{MHz}$, $\left.\mathrm{CDCl}_{3}\right) \delta 8.47\left(\mathrm{~d}, J 2.0 \mathrm{~Hz}, 1 \mathrm{H}, \mathrm{CH}_{\mathrm{Ar}}\right), 8.15(\mathrm{dd}, J 8.4$, $\left.2.0 \mathrm{~Hz}, 1 \mathrm{H}, \mathrm{C}_{\mathrm{Ar}}\right), 7.64\left(\mathrm{~d}, J 8.4 \mathrm{~Hz}, 1 \mathrm{H}, \mathrm{C}_{\mathrm{Ar}}\right), 4.40(\mathrm{t}$, $\left.2 \mathrm{H}, \mathrm{OC}_{2 \mathrm{Aliph}}\right), 3.60$ (t, $\left.2 \mathrm{H}, \mathrm{C}_{2} \mathrm{Cl}\right), 2.03-1.83(\mathrm{~m}, 4 \mathrm{H}$, $\left.\mathrm{C}_{2} \mathrm{C}_{2 \text { Aliph }}\right) ;{ }^{13} \mathrm{C}$ NMR $\left(101 \mathrm{MHz}, \mathrm{CDCl}_{3}\right) \delta 163.7,148.0$, 133.6, 132.2, 131.7, 130.2, 126.6, 65.4, 44.4, 29.1, 26.1.

\section{4-Chlorobutyl cinnamate (6j)}

Yellow liquid; yield: $60 \%$; MW $238.71 \mathrm{~g} \mathrm{~mol}^{-1}$; IR (ATR) $v / \mathrm{cm}^{-1} 1706(\mathrm{C}=\mathrm{O}), 1309,1165(\mathrm{C}-\mathrm{O}), 1278,767$ $(\mathrm{C}-\mathrm{Cl}) ;{ }^{1} \mathrm{H}$ NMR $\left(400 \mathrm{MHz}, \mathrm{CDCl}_{3}\right) \delta 7.69(\mathrm{~d}, J 16.0 \mathrm{~Hz}$, $\left.1 \mathrm{H}, \mathrm{C}_{\mathrm{H}_{\text {Olefin }}}\right), 7.52\left(\mathrm{dd}, J 5.6,4.1 \mathrm{~Hz}, 2 \mathrm{H}, \mathrm{C}_{\mathrm{Ar}}\right), 7.43-7.35$ $\left(\mathrm{m}, 3 \mathrm{H}, \mathrm{C}_{\mathrm{Ar}}\right), 6.43\left(\mathrm{~d}, J 16.0 \mathrm{~Hz}, 1 \mathrm{H}, \mathrm{C}_{\mathrm{H}}\right.$ Olefin $), 4.24$ (t, $\left.2 \mathrm{H}, \mathrm{OC}_{2 \mathrm{Aliph}}\right), 3.59$ (t, $\left.2 \mathrm{H}, \mathrm{C}_{2} \mathrm{Cl}\right), 1.97-1.82(\mathrm{~m}, 4 \mathrm{H}$, $\left.\mathrm{C}_{2} \mathrm{C}_{2}{ }_{2 \text { Aliph }}\right) ;{ }^{13} \mathrm{C}$ NMR $\left(101 \mathrm{MHz}, \mathrm{CDCl}_{3}\right) \delta 166.9,144.9$, 134.4, 130.4, 128.9, 128.1, 118.0, 63.7, 44.5, 29.2, 26.2.

\section{4-Chlorobutyl 3-nitro-cinnamate (6k)}

Yellow solid; yield: 64\%; MW $283.71 \mathrm{~g} \mathrm{~mol}^{-1}$; $\mathrm{mp} 41-43{ }^{\circ} \mathrm{C}$; IR (ATR) $v / \mathrm{cm}^{-1} 1708(\mathrm{C}=\mathrm{O}), 1323,1176$ $(\mathrm{C}-\mathrm{O}), 1529,1350(\mathrm{~N}=\mathrm{O}), 1205,744(\mathrm{C}-\mathrm{Cl}) ;{ }^{1} \mathrm{H}$ NMR $\left(500 \mathrm{MHz}, \mathrm{CDCl}_{3}\right) \delta 8.33\left(\mathrm{t}, J 1.9 \mathrm{~Hz}, 1 \mathrm{H}, \mathrm{CH}_{\mathrm{Ar}}\right), 8.18(\mathrm{dd}$, $\left.J 7.8,1.8 \mathrm{~Hz}, 1 \mathrm{H}, \underline{\mathrm{C}}_{\mathrm{Ar}}\right), 7.80\left(\mathrm{~d}, J 7.7 \mathrm{~Hz}, 1 \mathrm{H}, \underline{\mathrm{C}}_{\mathrm{Ar}}\right), 7.67$ $\left(\mathrm{d}, J 16.0 \mathrm{~Hz}, 1 \mathrm{H}, \underline{\mathrm{C}}_{\text {Olefin }}\right), 7.56\left(\mathrm{t}, J 8.0 \mathrm{~Hz}, 1 \mathrm{H}, \mathrm{C}_{\mathrm{Ar}}\right)$, $6.52\left(\mathrm{~d}, J 16.0 \mathrm{~Hz}, 1 \mathrm{H}, \mathrm{C}_{\text {Olefin }}\right), 4.23$ (t, $\left.2 \mathrm{H}, \mathrm{OC}_{2 \mathrm{H}}{ }_{\text {Aliph }}\right), 3.57$ (t, $\left.2 \mathrm{H}, \underline{\mathrm{C}}_{2} \mathrm{Cl}\right), 1.94-1.81$ (m, 4H, $\underline{\mathrm{C}}_{2} \mathrm{C}_{2 \mathrm{H}}$ Aliph $) ;{ }^{13} \mathrm{C} \mathrm{NMR}$ $\left(126 \mathrm{MHz}, \mathrm{CDCl}_{3}\right) \delta 166.0,148.6,141.9,136.1,133.6$, 130.0, 124.5, 122.4, 121.1, 64.0, 44.5, 29.1, 26.1 .

\section{4-Chlorobutyl 4-trifluormethyl-cinnamate (6I)}

Yellow liquid; yield: 55\%; MW $306.71 \mathrm{~g} \mathrm{~mol}^{-1}$; IR (ATR) v / $\mathrm{cm}^{-1} 1714(\mathrm{C}=\mathrm{O}), 1166,1066(\mathrm{C}-\mathrm{O}), 1321$ (C-F), 1282, $831(\mathrm{C}-\mathrm{Cl}) ;{ }^{1} \mathrm{H}$ NMR $\left(500 \mathrm{MHz}, \mathrm{CDCl}_{3}\right)$ $\delta 7.68\left(\mathrm{~d}, J 16.0 \mathrm{~Hz}, 1 \mathrm{H}, \underline{\mathrm{C}}_{\text {Olefin }}\right), 7.65-7.57\left(\mathrm{~m}, 4 \mathrm{H}, \mathrm{C}_{\mathrm{Ar}}\right)$,

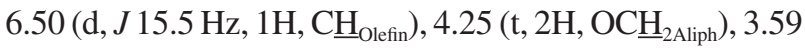
(t, $\left.2 \mathrm{H}, \underline{\mathrm{C}}_{2} \mathrm{Cl}\right), 2.02-1.77$ (m, 4H, $\underline{\mathrm{C}}_{2} \mathrm{C}_{2 \mathrm{Aliph}}$ ); ${ }^{13} \mathrm{C} \mathrm{NMR}$ $\left(126 \mathrm{MHz}, \mathrm{CDCl}_{3}\right) \delta 166.4,143.0,137.8,131.8,128.2$, 125.9, 125.0, 122.8, 120.6, 64.0, 44.5, 29.2, 26.2 .

4-Chlorobutyl 3-(2-thienyl-acrylate) (6m)

Yellow liquid; yield: 60\%; MW $244.74 \mathrm{~g} \mathrm{~mol}^{-1}$; IR (ATR) $v / \mathrm{cm}^{-1} 1705(\mathrm{C}=\mathrm{O}), 1157,1043(\mathrm{C}-\mathrm{O}), 1201,704$ $(\mathrm{C}-\mathrm{Cl}) ;{ }^{1} \mathrm{H}$ NMR $\left(400 \mathrm{MHz}, \mathrm{CDCl}_{3}\right) \delta 7.78(\mathrm{~d}, J 15.7 \mathrm{~Hz}$, $\left.1 \mathrm{H}, \underline{\mathrm{H}}_{\text {Olefin }}\right), 7.37\left(\mathrm{~d}, J 5.1 \mathrm{~Hz}, 1 \mathrm{H}, \underline{\mathrm{CH}}_{\mathrm{Ar}}\right), 7.25(\mathrm{~d}, J 3.6 \mathrm{~Hz}$, $\left.1 \mathrm{H}, \mathrm{C}_{\mathrm{Ar}}\right), 7.05\left(\mathrm{dd}, J 5.1,3.6 \mathrm{~Hz}, 1 \mathrm{H}, \mathrm{C}_{\mathrm{Ar}}\right), 6.23(\mathrm{~d}$, $\left.J 15.7 \mathrm{~Hz}, 1 \mathrm{H}, \mathrm{C}_{\text {Olefin }}\right), 4.22$ (t, $\left.2 \mathrm{H}, \mathrm{OC}_{2 \mathrm{Aliph}}\right), 3.59$ (t, $2 \mathrm{H}, \mathrm{C}_{2} \mathrm{Cl}$ ), 2.00-1.79 (m, 4H, $\left.\mathrm{C}_{2} \mathrm{C}_{2} \underline{\mathrm{H}}_{2 \mathrm{liph}}\right) ;{ }^{13} \mathrm{C} \mathrm{NMR}$ $\left(101 \mathrm{MHz}, \mathrm{CDCl}_{3}\right) \delta 166.8,139.5,137.4,131.0,128.6$, 128.1, 116.7, 63.7, 44.5, 29.2, 26.2.

\section{4-Chlorobutyl 2-(4-methoxyphenyl)-acetate (6n)}

Orange liquid; yield: $65 \%$; MW $256.73 \mathrm{~g} \mathrm{~mol}^{-1}$; IR (ATR) $v / \mathrm{cm}^{-1} 1732(\mathrm{C}=\mathrm{O}), 1246,1031(\mathrm{C}-\mathrm{O}), 1152,819$ $(\mathrm{C}-\mathrm{Cl}) ;{ }^{1} \mathrm{H} \mathrm{NMR}\left(400 \mathrm{MHz}, \mathrm{CDCl}_{3}\right) \delta 7.19(\mathrm{~d}, J 8.7 \mathrm{~Hz}$, $\left.2 \mathrm{H}, \mathrm{C}_{\mathrm{Ar}}\right), 6.85\left(\mathrm{~d}, J 8.7 \mathrm{~Hz}, 2 \mathrm{H}, \mathrm{C}_{\mathrm{Ar}}\right), 4.11(\mathrm{t}, 2 \mathrm{H}$, $\left.\mathrm{OC} \underline{\mathrm{H}}_{2 \mathrm{Aliph}}\right), 3.78$ (s, $3 \mathrm{H}, \mathrm{C}_{3} \mathrm{O}$ ), 3.55 (s, $\left.2 \mathrm{H}, \mathrm{C}_{2} \mathrm{C}_{\mathrm{Ar}}\right), 3.50$ (t, $2 \mathrm{H}, \mathrm{C}_{2} \mathrm{Cl}$ ), 1.81-1.74 (m, 4H, $\underline{\mathrm{C}}_{2} \mathrm{C}_{2} \underline{\mathrm{H}}_{2 \mathrm{liph}}$ ); ${ }^{13} \mathrm{C} \mathrm{NMR}$ $\left(101 \mathrm{MHz}, \mathrm{CDCl}_{3}\right) \delta 171.8,158.7,130.2,126.1,114.0$, 63.9, 55.2, 44.4, 29.1, 26.0.

\section{4-Chlorobutyl 2-(1,3-dioxoisoindolinyl)-acetate (60)}

Yellow liquid; yield: 67\%; MW $295.72 \mathrm{~g} \mathrm{~mol}^{-1}$; IR (ATR) $v / \mathrm{cm}^{-1} 1749,1718(\mathrm{C}=\mathrm{O}), 1193,1112(\mathrm{C}-\mathrm{O}), 1392$, $713(\mathrm{C}-\mathrm{Cl}) ;{ }^{1} \mathrm{H}$ NMR $\left(400 \mathrm{MHz}, \mathrm{CDCl}_{3}\right) \delta$ 7.92-7.81 (m, $\left.2 \mathrm{H}, \mathrm{C}_{\mathrm{Ar}}\right), 7.78-7.65\left(\mathrm{~m}, 2 \mathrm{H}, \underline{\mathrm{C}}_{\mathrm{Ar}}\right), 4.42\left(\mathrm{~s}, 2 \mathrm{H}, \mathrm{NC}_{2}\right)$, $4.18\left(\mathrm{t}, 2 \mathrm{H}, \mathrm{OC}_{2 \mathrm{Aliph}}\right), 3.52$ (t, $\left.2 \mathrm{H}, \mathrm{C}_{2} \mathrm{Cl}\right), 1.90-1.74$ (m, $\left.4 \mathrm{H}, \mathrm{C}_{2} \mathrm{C}_{2 \mathrm{Aliph}}\right) ;{ }^{13} \mathrm{C}$ NMR (101 MHz, $\left.\mathrm{CDCl}_{3}\right) \delta 167.5$, 167.3, 134.4, 132.0, 123.7, 66.0, 44.3, 38.9, 28.9, 25.9.

General procedure for new piperine derivatives (7a-70)

In a $25 \mathrm{~mL}$ flask containing $10 \mathrm{~mL}$ of DMF, $2.0 \mathrm{mmol}$ of the $\delta$-chloro-ester $(\mathbf{6 a - 6 o})$ and $2.0 \mathrm{mmol}$ potassium iodide were added. Next, $2.2 \mathrm{mmol}$ potassium piperate (3) were added, and after the salt addition, the reaction mixture was heated to $100{ }^{\circ} \mathrm{C}$ and remained under agitation for $24 \mathrm{~h}$. Afterwards, the reaction was cooled, and cold distilled water was added. The precipitate formed was vacuum filtered, washed with water and recrystallized in ethanol.

\section{Butyl 4-acetate-piperate (7a)}

Pale yellow solid; yield: 70\%; MW $332.35 \mathrm{~g} \mathrm{~mol}^{-1}$; mp 76-78 ${ }^{\circ} \mathrm{C}$; IR (ATR) $\mathrm{v} / \mathrm{cm}^{-1} 3057\left(\mathrm{C}-\mathrm{H}_{\mathrm{Ar}}\right), 2958,2899$ $(\mathrm{C}-\mathrm{H}), 1722,1707(\mathrm{C}=\mathrm{O}), 1620,1490\left(\mathrm{C}=\mathrm{C}_{\mathrm{Ar}}\right), 1251$ $\left(\mathrm{O}-\mathrm{CH}_{2}-\mathrm{O}\right), 1142,1035(\mathrm{C}-\mathrm{O}), 813\left(\mathrm{C}-\mathrm{H}_{\mathrm{Ar}}\right) ;{ }^{1} \mathrm{H}$ NMR $\left(400 \mathrm{MHz}\right.$, DMSO- $\left.d_{6}\right) \delta 7.38$ (ddd, $J 15.2,8.5,1.8 \mathrm{~Hz}$, $1 \mathrm{H}, \mathrm{H}-3), 7.24$ (d, $J 1.5 \mathrm{~Hz}, 1 \mathrm{H}, \mathrm{H}-7), 7.06-6.99$ (m, 3H, H-4, H-5, H-11), 6.94 (d, J 8.0 Hz, 1H, H-10), 6.06 (s, 2H, H-12), 6.00 (d, J $15.2 \mathrm{~Hz}, 1 \mathrm{H}, \mathrm{H}-2), 4.12$ (t, 2H, H-16), 4.04 (t, 2H, H-13), 2.01 (s, 3H, H-18), 1.77-1.61 (m, 4H, H-15, $\mathrm{H}-14) ;{ }^{13} \mathrm{C}$ NMR (101 MHz, DMSO- $\left.d_{6}\right) \delta 170.4$ (C-17), 166.2 (C-1), 148.2 (C-9), 148.0 (C-8), 145.1 (C-3), 140.5 (C-5), 130.4 (C-6), 124.6 (C-4), 123.2 (C-2), 119.7 (C-11), 108.5 (C-10), 105.7 (C-7), 101.4 (C-12), 63.4 (C-13), 63.3 (C-16), 24.9 (C-14), 24.8 (C-15), 20.7 (C-18). 


\section{Butyl 4-benzoate-piperate (7b)}

Pale yellow solid; yield: 74\%; MW $394.42 \mathrm{~g} \mathrm{~mol}^{-1}$; mp 92-93 ${ }^{\circ} \mathrm{C}$; IR (ATR) v / $\mathrm{cm}^{-1} 3059\left(\mathrm{C}-\mathrm{H}_{\mathrm{Ar}}\right), 2958$, $2885(\mathrm{C}-\mathrm{H}), 1708,1697(\mathrm{C}=\mathrm{O}), 1604,1444\left(\mathrm{C}=\mathrm{C}_{\mathrm{Ar}}\right), 1249$ $\left(\mathrm{O}-\mathrm{CH}_{2}-\mathrm{O}\right), 1132,1018(\mathrm{C}-\mathrm{O}), 702\left(\mathrm{C}-\mathrm{H}_{\mathrm{Ar}}\right) ;{ }^{1} \mathrm{H}$ NMR $\left(400 \mathrm{MHz}\right.$, DMSO- $d_{6}$ ) $\delta 7.97$ (dd, $J 8.4,1.3 \mathrm{~Hz}, 2 \mathrm{H}, \mathrm{H}-19$, H-19'), 7.69-7.62 (m, 1H, H-21), 7.53 (t, J 7.6 Hz, 2H, H-20, H-20') 7.36 (ddd, J 15.2, 7.3, 3.0 Hz, 1H, H-3), 7.22 (d, J 1.6 Hz, 1H, H-7), 7.03-6.96 (m, 3H, H-4, H-5, H-11), $6.93(\mathrm{~d}, J 8.0 \mathrm{~Hz}, 1 \mathrm{H}, \mathrm{H}-10), 6.05$ (s, 2H, H-12), 6.00 (d, $J 15.2 \mathrm{~Hz}, 1 \mathrm{H}, \mathrm{H}-2), 4.32$ (t, 2H, H-16), 4.17 (t, 2H, H-13), 1.95-1.68 (m, 4H, H-15, H-14); ${ }^{13} \mathrm{C}$ NMR (101 MHz, DMSO- $\left.d_{6}\right) \delta 166.2(\mathrm{C}-1), 165.7(\mathrm{C}-1), 148.2(\mathrm{C}-9), 148.0$ (C-8), $145.1(\mathrm{C}-3), 140.5(\mathrm{C}-5), 133.2(\mathrm{C}-21), 130.4(\mathrm{C}-6)$, 129.8 (C-18), 129.2 (C-19, C-19'), 128.6 (C-20, C-20'), 124.6 (C-4), 123.3 (C-11), 119.8 (C-2), 108.5 (C-10), 105.7 (C-7), 101.4 (C-12), 64.3 (C-16), 63.4 (C-13), 25.0 (C-15), 24.9 (C-14).

\section{Butyl 4-(4-chlorobenzoate)-piperate (7c)}

Pale yellow solid; yield: $71 \%$; MW $428.87 \mathrm{~g} \mathrm{~mol}^{-1}$; mp 124-125 ${ }^{\circ} \mathrm{C}$; IR (ATR) v / cm ${ }^{-1} 3068\left(\mathrm{C}-\mathrm{H}_{\mathrm{Ar}}\right), 2960$, $2897(\mathrm{C}-\mathrm{H}), 1708,1697(\mathrm{C}=\mathrm{O}), 1595,1444\left(\mathrm{C}=\mathrm{C}_{\mathrm{Ar}}\right)$, $1249\left(\mathrm{O}-\mathrm{CH}_{2}-\mathrm{O}\right), 1134,1020(\mathrm{C}-\mathrm{O}), 1282\left(\mathrm{C}_{\mathrm{Ar}}-\mathrm{Cl}\right)$, $754\left(\mathrm{C}-\mathrm{H}_{\mathrm{Ar}}\right) ;{ }^{1} \mathrm{H}$ NMR $\left(500 \mathrm{MHz}\right.$, DMSO- $\left.d_{6}\right) \delta 7.96(\mathrm{~d}$, $\left.J 8.5 \mathrm{~Hz}, 2 \mathrm{H}, \mathrm{H}-19, \mathrm{H}-19^{\prime}\right), 7.59$ (d, J $8.4 \mathrm{~Hz}, 2 \mathrm{H}, \mathrm{H}-20$, H-20'), 7.35 (ddd, J 15.3, 8.2, 1.6 Hz, 1H, H-3), 7.21 (s, $1 \mathrm{H}$, H-7), 7.02-6.94 (m, 3H, H-4, H-5, H11), 6.92 (d, J $8.0 \mathrm{~Hz}$, 1H, H-10), 6.05 (s, 2H, H-12), 5.99 (d, J $15.2 \mathrm{~Hz}, 1 \mathrm{H}, \mathrm{H}-2$ ), 4.31 (t, 2H, H-16), 4.16 (t, 2H, H-13), 1.83-1.74 (m, 4H, $\mathrm{H}-15, \mathrm{H}-14) ;{ }^{13} \mathrm{C}$ NMR (126 MHz, DMSO- $\left.d_{6}\right) \delta 166.2$ (C-1), 164.9 (C-17), 148.2 (C-9), 147.9 (C-8), 145.1 (C-3), 140.4 (C-5), 138.2 (C-21), 130.9 (C-19, C-19'), 130.4 (C-18), 128.9 (C-20, C-20'), 128.6 (C-6), 124.6 (C-4), 123.2 (C-11), 119.7 (C-2), 108.5 (C-10), 105.7 (C-7), 101.3 (C-12), 65.5 (C-16), 63.4 (C-13), 24.9 (C-15), 24.8 (C-14).

\section{Butyl 4-(4-bromobenzoate)-piperate (7d)}

Brown solid; yield: 70\%; MW $473.32 \mathrm{~g} \mathrm{~mol}^{-1}$; mp 127$129^{\circ} \mathrm{C}$; IR (ATR) v/ $\mathrm{cm}^{-1} 3062\left(\mathrm{C}-\mathrm{H}_{\mathrm{Ar}}\right), 2949,2897(\mathrm{C}-\mathrm{H})$, 1710, $1697(\mathrm{C}=\mathrm{O}), 1604,1442\left(\mathrm{C}=\mathrm{C}_{\mathrm{Ar}}\right), 1249\left(\mathrm{O}-\mathrm{CH}_{2}-\mathrm{O}\right)$, $1117,1134,1099(\mathrm{C}-\mathrm{O}), 842\left(\mathrm{C}-\mathrm{H}_{\mathrm{Ar}}\right) ;{ }^{1} \mathrm{H} \mathrm{NMR}(400 \mathrm{MHz}$, DMSO- $\left.d_{6}\right) \delta 7.89$ (d, $J 8.8 \mathrm{~Hz}, 2 \mathrm{H}, \mathrm{H}-20, \mathrm{H}-20$ ') 7.74 (d, $J 8.8$ Hz, 2H, H-19, H-19'), 7.36 (ddd, J 15.2, 7.5, 2.9 Hz, $1 \mathrm{H}, \mathrm{H}-3), 7.22$ (d, J 1.6 Hz, 1H, H-7), 7.03-6.97 (m, 3H, H-4, H-5, H-11), 6.93 (d, J 8.0 Hz, 1H, H-10), 6.05 (s, 2H, H-12), 5.99 (d, J 15.2 Hz, 1H, H-2), 4.31 (t, 2H, H-16), 4.16 (t, 2H, H-13), 1.87-1.65 (m, 4H, H-15, H-14); ${ }^{13} \mathrm{C}$ NMR (101 MHz, DMSO- $\left.d_{6}\right) \delta 166.2(\mathrm{C}-1), 165.0$ (C-17), 148.2 (C-9), 148.0 (C-8), 145.1 (C-3), 140.5 (C-5), 131.9 (C-19, C-19'), 131.1 (C-20, C-20'), 130.4 (C-6), 128.9 (C-18),
127.3 (C-21), 124.6 (C-4), 123.2 (C-11), 119.7 (C-2), 108.5 (C-10), 105.7 (C-7), 101.4 (C-12), 64.6 (C-16), 63.4 (C-13), 24.9 (C-15), 24.8 (C-14).

\section{Butyl 4-(4-iodobenzoate)-piperate (7e)}

Brown solid; yield: 64\%; MW $520.32 \mathrm{~g} \mathrm{~mol}^{-1}$; mp 162-163 ${ }^{\circ} \mathrm{C}$; IR (ATR) v / cm $3066\left(\mathrm{C}-\mathrm{H}_{\mathrm{Ar}}\right), 2958$, $2895(\mathrm{C}-\mathrm{H}), 1706,1697(\mathrm{C}=\mathrm{O}), 1618,1444\left(\mathrm{C}=\mathrm{C}_{\mathrm{Ar}}\right)$, $1249\left(\mathrm{O}-\mathrm{CH}_{2}-\mathrm{O}\right), 1174,1134,1037(\mathrm{C}-\mathrm{O}), 748\left(\mathrm{C}-\mathrm{H}_{\mathrm{Ar}}\right)$; ${ }^{1} \mathrm{H}$ NMR $\left(500 \mathrm{MHz}\right.$, DMSO- $\left.d_{6}\right) \delta 7.91(\mathrm{~d}, J 8.5 \mathrm{~Hz}, 2 \mathrm{H}$, H-20, H-20'), 7.71 (d, J 8.5 Hz, 2H, H-19, H-19'), 7.35 (ddd, $J$ 15.2, 8.1, 2.2 Hz, 1H, H-3), 7.22 (d, $J 1.6 \mathrm{~Hz}, 1 \mathrm{H}$, H-7), 7.02-6.96 (m, 3H, H-4, H-5, H-11), 6.92 (d, J 8.0 Hz, $1 \mathrm{H}, \mathrm{H}-10), 6.05$ (s, 2H, H-12), 5.99 (d, J $15.2 \mathrm{~Hz}, 1 \mathrm{H}, \mathrm{H}-2$ ), 4.30 (t, 2H, H-16), 4.16 (t, 2H, H-13), 1.82-1.73 (m, 4H, $\mathrm{H}-15, \mathrm{H}-14) ;{ }^{13} \mathrm{C}$ NMR (126 MHz, DMSO- $\left.d_{6}\right) \delta 166.2$ (C-1), 165.4 (C-17), 148.2 (C-9), 148.0 (C-8), 145.1 (C-3), 140.5 (C-5), 137.7 (C-20, C-20'), 130.8 (C-19, C-19'), 130.4 (C-6), 129.2 (C-18), 124.6 (C-4), 123.2 (C-11), 119.7 (C-2), 108.5 (C-10), 105.7 (C-7), 101.7 (C-21), 101.4 (C-12), 64.5 (C-16), 63.4 (C-13), 24.9 (C-15), 24.9 (C-14).

\section{Butyl 4-(4-methylbenzoate)-piperate (7f)}

Pale yellow solid; yield: 76\%; MW $408.45 \mathrm{~g} \mathrm{~mol}^{-1}$; mp 124-125 ${ }^{\circ} \mathrm{C}$; IR (ATR) v / cm ${ }^{-1} 3068\left(\mathrm{C}-\mathrm{H}_{\mathrm{Ar}}\right), 2964$, $2899(\mathrm{C}-\mathrm{H}), 1703(\mathrm{C}=\mathrm{O}), 1606,1452\left(\mathrm{C}=\mathrm{C}_{\mathrm{Ar}}\right), 1267$ $\left(\mathrm{O}-\mathrm{CH}_{2}-\mathrm{O}\right), 1236,1134,1014(\mathrm{C}-\mathrm{O}), 850\left(\mathrm{C}-\mathrm{H}_{\mathrm{Ar}}\right)$; ${ }^{1} \mathrm{H}$ NMR (400 MHz, DMSO- $d_{6}$ ) $\delta 7.85$ (d, $J 8.2 \mathrm{~Hz}, 2 \mathrm{H}$, H-19, H-19'), 7.40-7.34 (m, 1H, H-3), 7.32 (d, J 7.9 Hz, 2H, H-20, H-20'), 7.22 (d, J $1.5 \mathrm{~Hz}, 1 \mathrm{H}, \mathrm{H}-7$ ), 7.07-6.95 (m, 3H, H-4, H-5, H-11), 6.92 (d, J 8.0 Hz, 1H, H-10), 6.05 (s, 2H, H-12), 5.99 (d, J $15.2 \mathrm{~Hz}, 1 \mathrm{H}, \mathrm{H}-2), 4.28$ (t, $2 \mathrm{H}$, $\mathrm{H}-16$ ), 4.16 (t, 2H, H-13), 2.36 (s, 3H, H-22), 1.89-1.52 (m, 4H, H-15, H-14); ${ }^{13} \mathrm{C}$ NMR (101 MHz, DMSO- $d_{6}$ ) $\delta 166.3(\mathrm{C}-1), 165.7$ (C-17), 148.2 (C-9), 148.0 (C-8), 145.1 (C-3), 143.6 (C-21), 140.5 (C-5), 130.4 (C-6), 129.3 (C-19, C-19'), 129.1 (C-20, C-20'), 127.1 (C-18), 124.6 (C-4), 123.2 (C-11), 119.8 (C-2), 108.5 (C-10), 105.6 (C-7), 101.4 (C-12), 64.1 (C-16), 63.4 (C-13), 25.0 (C-15), 25.0 (C-14), 21.1 (C-22).

\section{Butyl 4-(4-nitrobenzoate)-piperate (7g)}

Yellow solid; yield: 78\%; MW $439.42 \mathrm{~g} \mathrm{~mol}^{-1}$; mp 128-129 ${ }^{\circ} \mathrm{C}$; IR (ATR) $\mathrm{v} / \mathrm{cm}^{-1} 3016\left(\mathrm{C}-\mathrm{H}_{\mathrm{Ar}}\right), 2947$, $2900(\mathrm{C}-\mathrm{H}), 1712,1695(\mathrm{C}=\mathrm{O}), 1523,1315(\mathrm{~N}=\mathrm{O}), 1604$, $1444\left(\mathrm{C}=\mathrm{C}_{\mathrm{Ar}}\right), 1249\left(\mathrm{O}-\mathrm{CH}_{2}-\mathrm{O}\right), 1136,1101,1020(\mathrm{C}-\mathrm{O})$, $840\left(\mathrm{C}-\mathrm{H}_{\mathrm{Ar}}\right) ;{ }^{1} \mathrm{H}$ NMR $\left(400 \mathrm{MHz}, \mathrm{DMSO}-d_{6}\right) \delta 8.33(\mathrm{~d}$, $J 9.0 \mathrm{~Hz}, 2 \mathrm{H}, \mathrm{H}-20, \mathrm{H}-20$ '), 8.19 (d, J $9.0 \mathrm{~Hz}, 2 \mathrm{H}, \mathrm{H}-19$, H-19'), 7.35 (ddd, $J 15.2,7.7,2.6 \mathrm{~Hz}, 1 \mathrm{H}, \mathrm{H}-3$ ), 7.21 (d, $J 1.6 \mathrm{~Hz}, 1 \mathrm{H}, \mathrm{H}-7$ ), 7.10-6.95 (m, 3H, H-4, H-5, H-11), 6.92 (d, J $8.0 \mathrm{~Hz}, 1 \mathrm{H}, \mathrm{H}-10), 6.05$ (s, 2H, H-12), 5.98 (d, 
$J 15.2 \mathrm{~Hz}, 1 \mathrm{H}, \mathrm{H}-2), 4.37$ (t, 2H, H-16), 4.17 (t, 2H, H-13), 2.03-1.43 (m, 4H, H-15, H-14); ${ }^{13} \mathrm{C}$ NMR (101 MHz, DMSO- $\left.d_{6}\right) \delta 166.2(\mathrm{C}-1), 164.3(\mathrm{C}-17), 150.2$ (C-21), 148.2 (C-9), 148.0 (C-8), 145.1 (C-3), 140.5 (C-5), 135.2 (C-18), 130.6 (C-6), 130.4 (C-19, C-19'), 124.6 (C-4), 123.8 (C-20, C-20'), 123.2 (C-11), 119.7 (C-2), 108.5 (C-10), 105.7 (C-7), 101.4 (C-12), 65.2 (C-16), 63.4 (C-13), 24.9 (C-15), 24.8 (C-14).

\section{Butyl 4-(3,5-dinitrobenzoate)-piperate (7h)}

Yellow solid; yield: $84 \%$; MW $484.42 \mathrm{~g} \mathrm{~mol}^{-1}$; $\mathrm{mp}$ $175-176^{\circ} \mathrm{C}$; IR (ATR) $v / \mathrm{cm}^{-1} 3103\left(\mathrm{C}-\mathrm{H}_{\mathrm{Ar}}\right), 2949(\mathrm{C}-\mathrm{H})$, 1730, $1701(\mathrm{C}=\mathrm{O}), 1550,1342(\mathrm{~N}=\mathrm{O}), 1618,1448\left(\mathrm{C}=\mathrm{C}_{\mathrm{Ar}}\right)$, $1253\left(\mathrm{O}-\mathrm{CH}_{2}-\mathrm{O}\right), 1139,1033,1016(\mathrm{C}-\mathrm{O}), 717\left(\mathrm{C}-\mathrm{H}_{\mathrm{Ar}}\right)$; ${ }^{1} \mathrm{H}$ NMR (400 MHz, DMSO- $\left.d_{6}\right) \delta 9.03(\mathrm{t}, J 2.1 \mathrm{~Hz}, 1 \mathrm{H}$, H-21), 8.91 (d, J 2.1 Hz, 2H, H-19, H-19'), 7.33 (dd, J 15.3, 9.7 Hz, 1H, H-3), 7.17 (s, 1H, H-7), 7.03-6.93 (m, 3H, H-4, H-5, H-11), 6.90 (d, J 8.0 Hz, 1H, H-10), 6.04 (s, 2H, H-12), 5.98 (d, J $15.2 \mathrm{~Hz}, 1 \mathrm{H}, \mathrm{H}-2$ ), 4.46 (t, 2H, H-16), 4.19 (t, 2H, H-13), 1.93-1.85 (m, 2H, H-15), 1.85-1.76 (m, 2H, H-14); ${ }^{13} \mathrm{C}$ NMR (101 MHz, DMSO- $\left.d_{6}\right) \delta 166.2$ (C-1), 162.5 (C-17), 148.3 (C-9), 148.1 (C-8), 147.9 (C20, C-20'), 145.0 (C-3), 140.4 (C-5), 132.8 (C-18), 130.4 (C-6), 128.7 (C-19, C-19'), 124.6 (C-4), 123.0 (C-11), 122.4 (C-21), 119.8 (C-2), 108.4 (C-10), 105.7 (C-7), 101.3 (C-12), 65.9 (C-16), 63.3 (C-13), 24.9 (C-14), 24.7 (C-15).

\section{Butyl 4-(4-chloro-3-nitrobenzoate)-piperate (7i)}

Yellow solid; yield: $66 \%$; MW $473.87 \mathrm{~g} \mathrm{~mol}^{-1}$; mp $102-104{ }^{\circ} \mathrm{C}$; IR (ATR) v / $\mathrm{cm}^{-1} 3070\left(\mathrm{C}-\mathrm{H}_{\mathrm{Ar}}\right), 2958$, $2899(\mathrm{C}-\mathrm{H}), 1712,1697(\mathrm{C}=\mathrm{O}), 1604,1313(\mathrm{~N}=\mathrm{O}), 1240$ $(\mathrm{C}-\mathrm{Cl}), 1541,1447\left(\mathrm{C}=\mathrm{C}_{\mathrm{Ar}}\right), 1251\left(\mathrm{O}-\mathrm{CH}_{2}-\mathrm{O}\right), 1215$, 1132, $1043(\mathrm{C}-\mathrm{O}), 806\left(\mathrm{C}-\mathrm{H}_{\mathrm{Ar}}\right)$; ${ }^{1} \mathrm{H}$ NMR $(500 \mathrm{MHz}$, DMSO- $\left.d_{6}\right) \delta 8.52(\mathrm{~d}, J 2.0 \mathrm{~Hz}, 1 \mathrm{H}, \mathrm{H}-19), 8.20(\mathrm{dd}, J 8.4$, $2.1 \mathrm{~Hz}, 1 \mathrm{H}, \mathrm{H}-23$ ), 7.93 (d, J 8.4 Hz, 1H, H-22), 7.34 (ddd, $J 15.2,8.7,1.6 \mathrm{~Hz}, 1 \mathrm{H}, \mathrm{H}-3), 7.21$ (d, J $1.5 \mathrm{~Hz}, 1 \mathrm{H}, \mathrm{H}-7$ ), 7.02-6.95 (m, 3H, H-4, H-5, H-11), 6.92 (d, J 8.1 Hz, 1H, H-10), 6.05 (s, 2H, H-12), 5.98 (d, J $15.2 \mathrm{~Hz}, 1 \mathrm{H}, \mathrm{H}-2$ ), 4.36 (t, 2H, H-16), 4.16 (t, 2H, H-13), 1.87-1.69 (m, 4H, $\mathrm{H}-15, \mathrm{H}-14) ;{ }^{13} \mathrm{C}$ NMR (126 MHz, DMSO- $\left.d_{6}\right) \delta 166.2$ (C-1), 163.4 (C-17), 148.2 (C-9), 148.0 (C-8), 147.9 (C-20), 145.1 (C-3), 140.5 (C-5), 133.8 (C-23), 132.4 (C-22), 130.4 (C-21), 130.0 (C-6), 129.8 (C-18), 126.0 (C-19), 124.6 (C-4), 123.2 (C-11), 119.7 (C-2), 108.5 (C10), 105.7 (C-7), 101.4 (C-12), 65.3 (C-16), 63.4 (C-13), 24.9 (C-14), 24.8 (C-15).

\section{Butyl 4-(cinnamate)-piperate (7j)}

Brown solid; yield: $60 \%$; MW $420.46 \mathrm{~g} \mathrm{~mol}^{-1}$; mp 86-88 ${ }^{\circ} \mathrm{C}$; IR (ATR) v / $\mathrm{cm}^{-1} 3034\left(\mathrm{C}-\mathrm{H}_{\mathrm{Ar}}\right), 2960$, $2897(\mathrm{C}-\mathrm{H}), 1705(\mathrm{C}=\mathrm{O}), 1608,1450\left(\mathrm{C}=\mathrm{C}_{\mathrm{Ar}}\right), 1267$
$\left(\mathrm{O}-\mathrm{CH}_{2}-\mathrm{O}\right), 1172,1136(\mathrm{C}-\mathrm{O}), 765\left(\mathrm{C}-\mathrm{H}_{\mathrm{Ar}}\right) ;{ }^{1} \mathrm{H}$ NMR $\left(500 \mathrm{MHz}, \mathrm{DMSO}-d_{6}\right) \delta 7.71$ (dd, $J 6.8,2.9 \mathrm{~Hz}, 2 \mathrm{H}, \mathrm{H}-21$, H-21'), 7.66 (d, J 16.1 Hz, 1H, H-19), 7.42 (d, J $2.5 \mathrm{~Hz}$, 3H, H-22, H-22', H-23), 7.37 (ddd, J 15.2, 8.4, $1.9 \mathrm{~Hz}, 1 \mathrm{H}$, H-3), 7.22 (d, J 1.6 Hz, 1H, H-7), 7.04-6.95 (m, 3H, H-4, H-5, H-11), 6.92 (d, J $8.0 \mathrm{~Hz}, 1 \mathrm{H}, \mathrm{H}-10), 6.63(\mathrm{~d}, J 16.0 \mathrm{~Hz}$, $1 \mathrm{H}, \mathrm{H}-18), 6.05$ (s, 2H, H-12), 6.00 (d, J $15.2 \mathrm{~Hz}, 1 \mathrm{H}, \mathrm{H}-2$ ), 4.19 (t, 2H, H-13), 4.15 (t, 2H, H-16), 1.79-1.69 (m, 4H, $\mathrm{H}-15, \mathrm{H}-16) ;{ }^{13} \mathrm{C}$ NMR (126 MHz, DMSO- $\left.d_{6}\right) \delta 166.2$ (C-1), 166.2 (C-17), 148.2 (C-9), 147.9 (C-8), 145.1 (C-3), 144.4 (C-19), 140.4 (C-5), 133.9 (C-20), 130.4 (C-6), 130.3 (C-23), 128.8 (C-22, C-22'), 128.3 (C-21, C-21'), 124.6 (C-4), 123.2 (C-11), 119.7 (C-2), 118.0 (C-18), 108.5 (C-10), 105.7 (C-7), 101.3 (C-12), 63.6 (C-13), 63.4 (C-16), 24.9 (C-14), 24.9 (C-15).

\section{Butyl 4-(3-nitro-cinnamate)-piperate (7k)}

Yellow solid; yield: $63 \%$; MW $465.46 \mathrm{~g} \mathrm{~mol}^{-1}$; $\mathrm{mp}$ $102-104{ }^{\circ} \mathrm{C}$; IR (ATR) $\mathrm{V} / \mathrm{cm}^{-1} 3072\left(\mathrm{C}-\mathrm{H}_{\mathrm{Ar}}\right), 2945,2902$ $(\mathrm{C}-\mathrm{H}), 1705,1695(\mathrm{C}=\mathrm{O}), 1529,1352(\mathrm{~N}=\mathrm{O}), 1604$, $1446\left(\mathrm{C}=\mathrm{C}_{\mathrm{Ar}}\right), 1253\left(\mathrm{O}-\mathrm{CH}_{2}-\mathrm{O}\right), 1176,1026(\mathrm{C}-\mathrm{O}), 862$ $\left(\mathrm{C}-\mathrm{H}_{\mathrm{Ar}}\right) ;{ }^{1} \mathrm{H}$ NMR $\left(500 \mathrm{MHz}, \mathrm{DMSO}-d_{6}\right) \delta 8.54(\mathrm{~s}, 1 \mathrm{H}$, H-21), 8.23 (d, J $8.1 \mathrm{~Hz}, 1 \mathrm{H}, \mathrm{H}-23), 8.19$ (d, J $7.4 \mathrm{~Hz}, 1 \mathrm{H}$, H-25), 7.78 (d, $J 16.1 \mathrm{~Hz}, 1 \mathrm{H}, \mathrm{H}-19), 7.69$ (t, $J 8.0 \mathrm{~Hz}$, 1H, H-24), 7.36 (dd, J 15.9, 9.2 Hz, 1H, H-3), 7.19 (s, 1H, H-7), 6.98 (m, 3H, H-4, H-5, H-11), 6.91 (d, J $8.0 \mathrm{~Hz}, 1 \mathrm{H}$, H-10), 6.84 (d, J 16.1 Hz, 1H, H-18), 6.04 (s, 2H, H-12), 5.99 (d, J $15.2 \mathrm{~Hz}, 1 \mathrm{H}, \mathrm{H}-2), 4.21$ (t, 2H, H-16), 4.16 (s, $2 \mathrm{H}, \mathrm{H}-13), 1.84-1.68$ (m, 4H, H-15, H-14); ${ }^{13} \mathrm{C}$ NMR (126 MHz, DMSO- $\left.d_{6}\right) \delta 166.2$ (C-1), 165.8 (C-17), 148.3 (C-22), 148.2 (C-9), 147.9 (C-8), 145.1 (C-3), 142.0 (C-19), 140.5 (C-5), 135.9 (C-20), 134.1 (C-25), 130.3 (C-6), 130.3 (C-24), 124.6 (C-4), 124.5 (C-23), 123.2 (C-11), 123.0 (C-21), 121.0 (C-18), 119.7 (C-2), 108.5 (C-10), 105.7 (C-7), 101.4 (C-12), 63.9 (C-13), 63.4 (C-16), 24.9 (C-14), 24.9 (C-15).

\section{Butyl 4-(4-trifluormethyl-cinnamate)-piperate (7I)}

Yellow solid; yield: 55\%; MW $488.46 \mathrm{~g} \mathrm{~mol}^{-1}$; mp 123-124 ${ }^{\circ} \mathrm{C}$; IR (ATR) $v / \mathrm{cm}^{-1} 3007\left(\mathrm{C}-\mathrm{H}_{\mathrm{Ar}}\right), 2964$, $2893(\mathrm{C}-\mathrm{H}), 1714,1701(\mathrm{C}=\mathrm{O}), 1610,1442\left(\mathrm{C}=\mathrm{C}_{\mathrm{Ar}}\right)$, $1249\left(\mathrm{O}-\mathrm{CH}_{2}-\mathrm{O}\right), 1165,1066$ (C-O), $1111(\mathrm{C}-\mathrm{F}), 844$ $\left(\mathrm{C}-\mathrm{H}_{\mathrm{Ar}}\right) ;{ }^{1} \mathrm{H}$ NMR $\left(400 \mathrm{MHz}, \mathrm{DMSO}-d_{6}\right) \delta 7.93(\mathrm{~d}$, $J 8.1 \mathrm{~Hz}, 1 \mathrm{H}, \mathrm{H}-21, \mathrm{H}-21$ '), 7.73 (dd, $J 15.7,9.6 \mathrm{~Hz}$, $3 \mathrm{H}, \mathrm{H}-22, \mathrm{H}-22$ ', H-19), 7.36 (ddd, $J$ 15.3, 7.4, $3.0 \mathrm{~Hz}$, $1 \mathrm{H}, \mathrm{H}-3), 7.21$ (d, J $1.5 \mathrm{~Hz}, 1 \mathrm{H}, \mathrm{H}-7), 7.02-6.95$ (m, $3 \mathrm{H}, \mathrm{H}-4, \mathrm{H}-5, \mathrm{H}-11), 6.91$ (d, J $8.0 \mathrm{~Hz}, 1 \mathrm{H}, \mathrm{H}-10), 6.78$ (d, $J 16.1 \mathrm{~Hz}, 1 \mathrm{H}, \mathrm{H}-18), 6.04$ (s, 1H, H-12), 6.00 (d, $J 15.2 \mathrm{~Hz}, 1 \mathrm{H}, \mathrm{H}-2), 4.21$ (t, 2H, H-16 ), 4.15 (t, 2H, H-13), 1.81-1.62 (m, 4H, H-15, H-14); ${ }^{13} \mathrm{C}$ NMR (101 MHz, DMSO- $\left.d_{6}\right) \delta 166.3$ (C-1), 165.9 (C-17), 148.2 (C-9), 
$148.0(\mathrm{C}-8), 145.2(\mathrm{C}-3), 142.6(\mathrm{C}-19), 140.5(\mathrm{C}-5), 138.0$ (C-20), 130.4 (C-6), 129.9 (C-23), 129.0 (C-21, C-21'), 125.8 (C-22, C-22'), 125.7 (C-22, C-22'), 125.3 (C-24), 124.6 (C-4), 123.3 (C-11), 121.0 (C-18), 119.8 (C-2), 108.5 (C-10), 105.7 (C-7), 101.4 (C-12), 63.9 (C-13), 63.4 (C-16), 25.0 (C-14), 24.9 (C-15).

\section{Butyl 4-(3-(2-thienyl acrylate))-piperate (7m)}

Yellow solid; yield: 52\%; MW $426.46 \mathrm{~g} \mathrm{~mol}^{-1}$; $\mathrm{mp} 87-88^{\circ} \mathrm{C}$; IR (ATR) $v / \mathrm{cm}^{-1} 3020\left(\mathrm{C}-\mathrm{H}_{\mathrm{Ar}}\right), 2897(\mathrm{C}-\mathrm{H})$, $1703(\mathrm{C}=\mathrm{O}), 1618,1452\left(\mathrm{C}=\mathrm{C}_{\mathrm{Ar}}\right), 1267\left(\mathrm{O}-\mathrm{CH}_{2}-\mathrm{O}\right), 1163$, $1136(\mathrm{C}-\mathrm{O}), 835\left(\mathrm{C}-\mathrm{H}_{\mathrm{Ar}}\right) ;{ }^{1} \mathrm{H}$ NMR $\left(400 \mathrm{MHz}, \mathrm{DMSO}-d_{6}\right)$ $\delta 7.80(\mathrm{~d}, J 15.8 \mathrm{~Hz}, 1 \mathrm{H}, \mathrm{H}-21), 7.71(\mathrm{~d}, J 5.1 \mathrm{~Hz}, 1 \mathrm{H}$, H-23), 7.54 (d, J 3.5 Hz, 1H, H-19), 7.36 (ddd, $J$ 15.2, 7.8, $2.5 \mathrm{~Hz}, 1 \mathrm{H}, \mathrm{H}-3), 7.21(\mathrm{~d}, J 1.5 \mathrm{~Hz}, 1 \mathrm{H}, \mathrm{H}-7), 7.14$ (dd, J 5.0, 3.6 Hz, 1H, H-22), 7.04-6.95 (m, 3H, H-4, H-5, $\mathrm{H}-11), 6.91(\mathrm{~d}, J 8.0 \mathrm{~Hz}, 1 \mathrm{H}, \mathrm{H}-10), 6.26(\mathrm{~d}, J 15.8 \mathrm{~Hz}$, 1H, H-18), 6.04 (s, 2H, H-12), 5.99 (d, J $15.2 \mathrm{~Hz}, 1 \mathrm{H}$, $\mathrm{H}-2$ ), 4.23-4.05 (m, 4H, H-16, H-13), 1.82-1.63 (m, 4H, $\mathrm{H}-15, \mathrm{H}-14) ;{ }^{13} \mathrm{C}$ NMR (101 MHz, DMSO- $\left.d_{6}\right) \delta 166.7$ (C-1), 166.4 (C-17), 148.7 (C-9), 148.4 (C-8), 145.6 (C-3), 140.9 (C-5), 139.1 (C-20), 137.6 (C-19), 132.5 (C-21), 130.8 (C-6), 130.3 (C-23), 129.0 (C-22), 125.1 (C-4), 123.7 (C-11), 120.2 (C-2), 116.6 (C-18), 108.9 (C-10), 106.2 (C-7), 101.8 (C-12), 64.1 (C-13), 63.8 (C-16), 25.4 (C-14), 25.4 (C-15).

\section{Butyl 4-(2-(4-methoxyphenyl)-acetate)-piperate (7n)}

Yellow-colored viscous liquid; yield: $50 \%$; MW $438.48 \mathrm{~g} \mathrm{~mol}^{-1}$; IR (ATR) $v / \mathrm{cm}^{-1} 3030\left(\mathrm{C}-\mathrm{H}_{\mathrm{Ar}}\right), 2956$, $2900(\mathrm{C}-\mathrm{H}), 1730,1705(\mathrm{C}=\mathrm{O}), 1608,1446\left(\mathrm{C}=\mathrm{C}_{\mathrm{Ar}}\right)$, $1246\left(\mathrm{O}-\mathrm{CH}_{2}-\mathrm{O}\right), 1168,1132,1033(\mathrm{C}-\mathrm{O}), 808\left(\mathrm{C}-\mathrm{H}_{\mathrm{Ar}}\right)$; ${ }^{1} \mathrm{H}$ NMR $\left(400 \mathrm{MHz}, \mathrm{CDCl}_{3}\right) \delta$ 7.45-7.36 (m, 1H, H-3), 7.19 (d, J 8.7 Hz, 2H, H-20, H-20'), 6.98 (d, J $1.6 \mathrm{~Hz}, 1 \mathrm{H}$, H-7), 6.92-6.76 (m, 5H, H-5, H-11, H-21, H-21', H-10), 6.69 (dd, J 15.5, $10.8 \mathrm{~Hz}, 1 \mathrm{H}, \mathrm{H}-4), 5.97$ (s, 2H, H-12), 5.92 (d, J 15.2 Hz, 1H, H-2), 4.28-4.05 (m, 4H, H-13, H-16), 3.77 (s, 3H, H-23), 3.55 (s, 2H, H-18), 1.86-1.61 (m, 4H, $\mathrm{H}-15, \mathrm{H}-14) ;{ }^{13} \mathrm{C}$ NMR $\left(101 \mathrm{MHz}, \mathrm{CDCl}_{3}\right) \delta 171.9(\mathrm{C}-17)$, 167.0 (C-1), 158.6 (C-22), 148.5 (C-9), 148.2 (C-8), 144.9 (C-3), 140.3 (C-19), 130.5 (C-6), 130.2 (C-20, C-20'), 126.1 (C-19), 124.4 (C-4), 122.9 (C-11), 120.1 (C-2), 113.9 (C-21, C-21'), 108.5 (C-10), 105.8 (C-7), 101.4 (C-12), 64.3 (C-16), 63.7 (C-13), 55.2 (C-23), 40.4 (C-18), 25.3 (C-15), 25.3 (C-14).

Butyl 4-(2-(1,3-dioxoisoindolinyl)-acetate)-piperate (7o)

Brown solid; yield: 58\%; MW $477.47 \mathrm{~g} \mathrm{~mol}^{-1}$; mp 97-99 ${ }^{\circ} \mathrm{C}$; IR (ATR) v / $\mathrm{cm}^{-1} 3014\left(\mathrm{C}-\mathrm{H}_{\mathrm{Ar}}\right), 2947$, $2889(\mathrm{C}-\mathrm{H}), 1745,1707(\mathrm{C}=\mathrm{O}), 1618,1492\left(\mathrm{C}=\mathrm{C}_{\mathrm{Ar}}\right), 1255$ $\left(\mathrm{O}-\mathrm{CH}_{2}-\mathrm{O}\right), 1138,1031(\mathrm{C}-\mathrm{O}), 711\left(\mathrm{C}-\mathrm{H}_{\mathrm{Ar}}\right) ;{ }^{1} \mathrm{H}$ NMR
(400 MHz, DMSO- $\left.d_{6}\right) \delta$ 7.94-7.89 (m, 2H, H-22, H-22'), 7.89-7.85 (m, 2H, H-21, H-21'), 7.34 (ddd, J 15.3, 8.5, $1.7 \mathrm{~Hz}, 1 \mathrm{H}, \mathrm{H}-3), 7.20$ (d, J 1.1 Hz, 1H, H-7), 7.02-6.95 (m, $3 \mathrm{H}, \mathrm{H}-4, \mathrm{H}-5, \mathrm{H}-11), 6.90$ (d, J $8.0 \mathrm{~Hz}, 1 \mathrm{H}, \mathrm{H}-10), 6.02$ (s, 2H, H-12), 5.98 (dd, J 15.2, $5.9 \mathrm{~Hz}, 1 \mathrm{H}, \mathrm{H}-2), 4.43$ (s, 2H, $\mathrm{H}-18), 4.14$ (t, 2H, H-16), 4.08 (t, 2H, H-13), 1.74-1.49 (m, $4 \mathrm{H}, \mathrm{H}-15, \mathrm{H}-14) ;{ }^{13} \mathrm{C}$ NMR (101 MHz, DMSO- $\left.d_{6}\right) \delta 167.7$ (C-17), 167.2 (C-1), 166.3 (C-19, C-19'), 148.3 (C-9), 148.1 (C-8), 145.2 (C-3), 140.6 (C-5), 135.0 (C-22, C-22'), 131.4 (C-20, C-20'), 130.5 (C-6), 124.7 (C-4), 123.5 (C-21, C-21'), 123.3 (C-11), 119.8 (C-2), 108.6 (C-10), 105.8 (C-7), 101.5 (C-12), 65.0 (C-16), 63.4 (C-13), 38.9 (C-18), 24.8 (C-15), 24.8 (C-14).

\section{In silico study}

The ADME (absorption, distribution, metabolism, and excretion) properties of the final compounds were calculated using the Molinspiration online program, ${ }^{26}$ in order to calculate the parameters of Lipinski's rule of five: clogP, MW, HBA, HBD and TPSA. The parameters $\log \mathrm{S}$, drug-likeness and drug-score were calculated with the OSIRIS Property Explorer software. ${ }^{24}$ The compounds absorption percentage was calculated using the equation: $\operatorname{ABS}(\%)=109-0.345$ TPSA. $^{27}$

\section{Antimicrobial activity}

\section{Culture media}

For maintenance of bacterial and fungal strains, the culture media used were brain heart infusion (BHI) and Sabouraud dextrose agar (SDA) (acquired from Difco Laboratories Ltd., Detroit, USA), respectively. For biological activity assays, BHI liquid nutrient medium was used for bacteria and Roswell Park Memorial Institute (RPMI) 1640 with L-glutamine and without bicarbonate for fungi (Difco Laboratories Ltd., Detroit, USA and INLAB, São Paulo, Brazil). All media have been prepared according to the descriptions of the manufacturers.

\section{Microorganisms}

In the antimicrobial activity assays of the compounds, the following strains were used: bacteria: Staphylococcus aureus (American Type Culture Collection (ATCC)-25923), Pseudomonas aeruginosa (ATCC-25853); yeasts: Candida albicans (ATCC-60193; LM-92), Candida tropicalis (ATCC-13803; LM-18); filamentous fungi: Aspergillus fumigatus (ATCC-40640; IPP-210), Aspergillus flavus (LM-714), Aspergillus niger (LM-108). The microorganisms were obtained from the collection of the Mycology Laboratory, Department of 
Pharmaceutical Sciences (DCF), Health Sciences Center (CCS) of the Federal University of Paraíba (UFPB), Brazil. The fungal and bacterial strains were maintained at $4{ }^{\circ} \mathrm{C}$ in SDA and BHI, respectively. For use in the assays, the fungi and bacteria were harvested in SDA and BHI, respectively, and incubated at $35 \pm 2{ }^{\circ} \mathrm{C}$ for $24-48 \mathrm{~h}$. The filamentous fungi were harvested in SDA and incubated at room temperature $\left(28 \pm 2{ }^{\circ} \mathrm{C}\right)$ for $7-14$ days. The microorganism suspension was prepared in sterile saline solution $(0.9 \% \mathrm{NaCl})$ and compared to the $0.5 \mathrm{McFarland}$ scale tube in order to obtain an inoculum of approximately $10^{6}$ and $10^{8}$ colony forming units (CFU) $\mathrm{mL}^{-1}$ for fungi and bacteria, respectively.

\section{Determination of minimum inhibitory concentration (MIC)}

The determination of the samples MIC on the selected strains was performed by the broth microdilution method in a 96-wells microplate for cellular culture with U-shaped bottom (TPP, Trasadingen, Switzerland). The tested compounds were weighed and solubilized in DMSO at 5\% and Tween- 80 at $2 \%$, completing the volume with sterile distilled water for obtaining an emulsion of the products with an initial concentration of $1024 \mu \mathrm{g} \mathrm{mL}{ }^{-1} .{ }^{28-30}$ Initially, $100 \mu \mathrm{L}$ of double-concentrated RPMI/BHI broth was distributed in the wells of the microdilution plates. Then, $100 \mu \mathrm{L}$ of the substances were dispensed into the wells of the first line of the plate. By means of a serial dilution at a ratio of two, concentrations of 1024 to $64 \mu \mathrm{g} \mathrm{mL}-1$ were obtained. Finally, $10 \mu \mathrm{L}$ of the bacterial and fungal inoculum was added to the wells, in which each column of the plate referred specifically to a species.

In parallel, the following controls were performed: microorganisms (BHI + bacteria and RPMI + yeasts or filamentous fungi) and culture medium (RPMI/BHI), to assure the viability of the strains and sterility of the medium; and negative control with antibiotics: gentamicin $\left(64 \mu \mathrm{g} \mathrm{m}^{-1}\right)$ for bacterial inhibition and amphotericin B $\left(32 \mu \mathrm{g} \mathrm{mL}{ }^{-1}\right)$ for fungal inhibition. The plates were incubated at $35 \pm 2{ }^{\circ} \mathrm{C}$ during $24-48 \mathrm{~h}$ for the assays with bacteria and yeasts, while the filamentous fungi were incubated at $28 \pm 2{ }^{\circ} \mathrm{C}$ for 7 days. In the biological assay with bacteria, $20 \mu \mathrm{L}$ of $0.01 \%$ resazurin dye solution (INLAB, São Paulo, Brazil) was added after $24 \mathrm{~h}$ of incubation, recognized as a colorimetric indicator of oxide-reduction. ${ }^{31}$ The color change of the dye (blue to red) was considered as an indicator of microbial growth, in which the permanence of the blue color means the absence of microbial growth. The MIC for each product was defined as the lowest concentration capable of visually inhibiting microbial growth and/or verified by the permanence of the color of the indicator dye.

\section{Supplementary Information}

Supplementary information is available free of charge at http://jbcs.sbq.org.br as PDF file.

\section{Acknowledgments}

This work was supported by the Brazilian agencies, CNPq, CAPES and FAPESQ-PB. Jônatas G. R. Martins provided English editing of the manuscript.

\section{Author Contributions}

Emmely O. Trindade and Petrônio F. de AthaydeFilho conceived and designated the experiment; Emmely O. Trindade, Thalisson F. Dutra, Maria C. R. Brandão and Bruno F. Lira performed the experiments; Emmely O. Trindade and Maria C. R. Brandão performed the in silico study and analyzed the data; Hermes Diniz Neto and Edeltrudes O. Lima performed the antimicrobial study; Emmely O. Trindade, Petrônio F. de Athayde-Filho and José M. Barbosa-Filho wrote the paper.

\section{References}

1. Lemos, O. F.; Tremalcodi, C. R.; Poltronieri, M. C.; Boas Práticas Agrícolas para Aumento da Produtividade e Qualidade da Pimenta-do-Reino no Estado do Pará, $1^{\text {st }}$ ed.; Embrapa: Brasília, Brazil, 2014.

2. Chuchawankul, S.; Khorana, N.; Poovorawan, Y.; Genet. Mol. Res. 2012, 11, 617.

3. Carnevalli, D. B.; Araújo, A. P. S.; Uniciências 2013, 17, 41.

4. Smilkov, K.; Ackova, D. G.; Cvetkovski, A.; Ruskovska, T.; Vidovic, B.; Atalay, M.; Curr. Pharm. Des. 2019, 25, 1729.

5. Chinta, G.; Syed, S. B.; Coumar, M. S.; Periyasamy, L.; Curr. Bioact. Compd. 2015, 11, 156.

6. Siddiqui, S.; Ahamad, M. S.; Jafri, A.; Afzal, M.; Arshad, M.; Nutr. Cancer 2017, 69, 791.

7. Rather, R. A.; Bhagat, M.; Front. Cell Dev. Biol. 2018, 6, 10.

8. Figueredo, A. S.; Oliveira, M. G.; Safadi, G. M. V. V.; Silva, C. H. T. P.; Silva, V. B.; Taft, C. A.; Aquino, G. L. B.; Curr. Phys. Chem. 2015, 5, 294.

9. Ali, Y.; Alam, M. S.; Hamid, H.; Husain, A.; Bano, S.; Dhulap, A.; Kharbanda, C.; Nazreen, S.; Haider, S.; Eur. J. Med. Chem. 2015, 92, 490.

10. Amperayani, K. R.; Kumar, K. N.; Parimi, U. D.; Res. Chem. Intermed. 2018, 44, 3549.

11. Santos, J.; Brito, M.; Ferreira, R.; Moura, A.; Sousa, T.; Batista, T.; Mangueira, V.; Leite, F.; Cruz, R.; Vieira, G.; Lira, B.; AthaydeFilho, P.; Souza, H.; Costa, N.; Veras, R.; Barbosa-Filho, J.; Magalhães, H.; Sobral, M.; Int. J. Mol. Sci. 2018, 19, 2594. 
12. Kharbanda, C.; Alam, M. S.; Hamid, H.; Javed, K.; Bano, S.; Ali, Y.; Dhulap, A.; Alam, P.; Pasha, M. A. Q.; Chem. Biol. Drug Des. 2016, 88, 354.

13. Franklim, T. N.; Freire-de-Lima, L.; Chaves, O. A.; LaRocquede-Freitas, I. F.; da Silva-Trindade, J. D.; Netto-Ferreira, J. C.; Freire-de-Lima, C. G.; Decoté-Ricardo, D.; Previato, J. O.; Mendonça-Previato, L.; de Lima, M. E. F.; J. Braz. Chem. Soc. 2019, 30, 1378.

14. Venkatasamy, R.; Faas, L.; Young, A. R.; Raman, A.; Hider, R. C.; Bioorg. Med. Chem. 2004, 12, 1905.

15. Ventola, C. L.; Pharm. Ther. 2015, 40, 277.

16. Almeida, F.; Rodrigues, M. L.; Coelho, C.; Front. Microbiol. 2019, 10, 214.

17. Kumar, K. N.; Amperayani, K. R.; Ummdi, V. R. S.; Parimi, U. D.; Asian J. Chem. 2019, 31, 1077.

18. Ikan, R.; Natural Products: A Laboratory Guide, $2^{\text {nd }}$ ed.; Academic Press: San Diego, USA, 1991.

19. Enthaler, S.; Weidauer, M.; Catal. Lett. 2012, 142, 168.

20. Lipinski, C. A.; Lombardo, F.; Paul, D.; Feeney, P. J.; Adv. Drug Delivery Rev. 1997, 23, 3.

21. Lipinski, C. A.; Lombardo, F.; Dominy, B. W.; Feeney, P. J.; Adv. Drug Delivery Rev. 2001, 46, 3.

22. Lipinski, C. A.; Drug Discovery Today: Technol. 2004, 1, 337.
23. https://www.organic-chemistry.org/prog/peo/, accessed in June 2020.

24. Graf, K.; Last, A.; Gratz, R.; Allert, S.; Linde, S.; Westermann, M.; Gröger, M.; Mosig, A. S.; Gresnigt, M. S.; Hube, B.; Dis. Models Mech. 2019, 12, dmm039719.

25. Choochana, P.; Moungjaroen, J.; Jongkon, N.; Gritsanapan, W.; Tangyuenyongwatana, P.; Pharm. Biol. 2015, 53, 477.

26. http://www.molinspiration.com, accessed in June 2020.

27. Zhao, Y. H.; Abraham, M. H.; Le, J.; Hersey, A.; Luscombe, C. N.; Beck, G.; Sherborne, B.; Cooper, I.; Pharm. Res. 2002, 19, 1446.

28. Cleland, R.; Squires, E. In Antibiotics in Laboratory Medicine; Lorian, V., ed.; Lippincott Williams \& Wilkins: Baltimore, 1991, p. 739.

29. Nascimento, P. F. C.; Nascimento, A. C.; Rodrigues, C. S.; Antoniolli, A. R.; Santos, M. P. O.; Júnior, A. M. B.; Trindade, R. C.; Rev. Bras. Farmacogn. 2007, 17, 108.

30. Pereira, F. O.; Mendes, J. M.; Lima, I. O.; Mota, K. S. L.; Oliveira, W. A.; Lima, E. O.; Pharm. Biol. 2015, 53, 228.

31. Mann, C. M.; Markham, J. L.; J. Appl. Microbiol. 1998, 84, 538.

Submitted: April 10, 2020

Published online: July 9, 2020 